\title{
Taxonomic revision of Spectracanthicus Nijssen \& Isbrücker (Loricariidae: Hypostominae: Ancistrini), with description of three new species
}

\author{
Carine C. Chamon ${ }^{1,2}$ and Lúcia H. Rapp Py-Daniel ${ }^{3}$
}

\begin{abstract}
A taxonomic review of Spectracanthicus Nijssen \& Isbrücker, including Oligancistrus Rapp Py-Daniel, following a phylogenetic study, is presented. Additionally to S. punctatissimus (Steindachner) and S. murinus Nijssen \& Isbrücker, three new species are recognized based on the examination of 159 specimens: S. immaculatus $n$. sp. from rio Tapajós basin, differs from its congeners by its color pattern consisting of a dark gray body, with no dots or spots, and by having very slender teeth; Spectracanthicus tocantinensis $\mathrm{n}$. sp., from the rio Tocantins drainage is distinguished by the color pattern consisting of dark brown or black body with small, yellowish dots (except in S. punctatissimus), presence of thick teeth, infraorbital 4 forming most of the posterior edge of the orbit and the large basipterigium fenestrae; and Spectracanthicus zuanoni n. sp., from the rio Xingu basin is diagnosed by its color pattern consisting of large, white spots and by the larger orbital diameter. Other characters based on osteological features are also usefull to distinguish the species. A key to the species of the genus and a brief discussion of their threats and conservation are also provided.

A revisão taxonômica de Spectracanthicus Nijssen \& Isbrücker, incluindo Oligancistrus Rapp Py-Daniel, baseada em estudos filogenéticos recentes, é apresentada. Adicionalmente a S. punctatissimus (Steindachner) e S. murinus Nijssen \& Isbrücker, três espécies novas são reconhecidas baseadas no exame de 159 espécimes: $S$. immaculatus, sp. n. proveniente da bacia do rio Tapajós, difere de suas congêneres pelo padrão de colorido do corpo cinza escuro sem pontos ou manchas e por possuir dentes bastante delgados; Spectracanthicus tocantinensis sp. n., da bacia do rio Tocantins pode ser distinguida pelo padrão de colorido do corpo marron escuro ou preto com pontos amarelados (exceto de S. punctatissimus), presença de dentes espessos, infraorbital 4 formando quase toda a margem posterior da órbita e pela presença de uma grande fenestra no basipterígio; e Spectracanthicus zuanoni sp. n., da bacia do rio Xingu é diagnosticada pelo padrão de colorido cinza escuro com grandes pontos brancos e por possuir maior diâmetro infraorbital. Outros caracteres osteológicos também podem ser utilizados para distinguir as espécies. Uma chave para as espécies do gênero e uma breve discussão sobre suas ameaças e conservação são também fornecidas.
\end{abstract}

Key words: Acari fish, Aquarism, Amazon basin, Armored Catfish, Ornamental fishery.

\section{Introduction}

The Loricariidae is the largest family within Siluriformes and includes more than 750 species, which represent about $25 \%$ of the diversity of catfishes (Reis et al., 2003; Ferraris, 2007). The family is widely distributed in the Neotropical region, from southeastern Costa Rica to northeastern Argentina (Isbrücker, 1980) and can be found in a large variety of freshwater environments. Loricariidae species are usually divided into historically unstable subfamilies, most of them apparently monophyletic (Loricariinae, Hypoptopomatinae, Lithogeninae, and Delturinae; Reis et al., 2006). However, the monophyly and composition of Hypostominae and Ancistrinae are still under scrutiny (Reis et al., 2003; Ferraris, 2007).

Different hypotheses of rearrangement of the Hypostominae have been proposed over the years (Regan, 1904; Gosline, 1947; Isbrücker, 1980; Schaefer, 1987; Armbruster, 2004), and the subfamily was considered paraphyletic by several authors

${ }^{1}$ Museu de Zoologia da Universidade de São Paulo. Caixa Postal 04218-970 São Paulo, SP, Brazil.

${ }^{2}$ Universidade de Brasília - UnB, Câmpus Universitário Darcy Ribeiro, Instituto de Biologia - IB, Departamento de Zoologia, 70910-970 Brasília, DF, Brazil. chamon.carine@gmail.com

${ }^{3}$ Instituto Nacional de Pesquisas da Amazônia, Coordenação de Pesquisas em Biologia Aquática., Manaus, AM, Brazil. rapp@inpa.gov.br 
(Armbruster, 2004; Schaefer 1987; Montoya-Burgos et al., 1998). The subfamily is currently recognized as comprising the tribes Ancistrini (= Ancistrinae sensu Isbrücker, 1980), Hypostomini, Corymbophanini, Pterygoplichthyini, and Rhinelepini (Armbruster, 2004). Although the Ancistrini is not diagnosed by a unique characters (Armbruster, 2004), most of its genera are readily recognized by having the opercle modified into a rectangular bar- or sickle-shaped structure with associated eversible plates supporting hypertrophied odontodes. However, this character is apparently reversed in some taxa, and the opercle has triangular or oval shaped, which is the plesiomorphic state within Hypostominae (i.e., Spectracanthicus and Hypostomus).

Spectracanthicus Nijssen \& Isbrücker was established as a monotypic genus to include $S$. murinus from the rio Tapajós basin. Recently, the genus Oligancistrus Rapp Py-Daniel was proposed as a junior synonym of Spectracanthicus by Armbruster (2004) based in the argument of an unnecessary recognition of two monotypic closely related genera. Chamon (2012) further corroborates such hypothesis in a phylogenetic study of the Acanthicus group, which resulted in Oligancistrus as paraphyletic, given that Oligancistrus punctatissimus as well as the new species fitting the diagnosis of that genus, represented successive sister-groups of Spectracanthicus murinus further justifying the synonymy proposed by Armbruster (2004). The genus is originally distinguished from other Ancistrini by the presence of an expansion of the dorsalfin membrane connecting it to the adipose-fin spine and the presence of up to 25 teeth on premaxilla. Herein, a taxonomic revision of Spectracanthicus is presented. In addition, a brief phylogenetic discussion on the relationships and a key to the species of the genus are provided.

\section{Material and Methods}

Measurements and counts were made according to Rapp PyDaniel \& Zuanon (2005). Specimens were cleared and stained (c\&s) according to Taylor \& Van Dyke (1985). Osteological nomenclature and vertebral counts follow Schaefer (1987) and Armbruster (2004). Vertebral counts include the first five vertebrae modified into Webberian apparatus, and the fused pre-ural centrum is counted as a single element. Terminology for the laterosensory system of the head follows Arratia \& Huaquin (1995); homologies of the preopercle sensory canal follow Schaefer (1988). Material examined was described in the following order: Institution number, count, measurements of minimum and maximum, locality, geographical coordinates, date of collection, and collectors. Some lots have missing data concerning date of collection and/or collectors. Specimens examined belong to the following institutions: Instituto Nacional de Pesquisas da Amazônia, Manaus (INPA), Field Museum of Natural History, Chicago (FMNH), Muséum d'histoire naturelle de la Ville de Genève, Geneva (MHNG), Museu Nacional, Universidade Federal do Rio de Janeiro, Rio de Janeiro. (MNRJ), Museu de Zoologia da Universidade de São Paulo, São Paulo (MZUSP), Naturhistorisches Museum Wien, Viena (NMW), Smithsonian Institution, National Museum of Natural History, Washington D.C. (USNM), and Zoological Museum of Amsterdam (ZMA) now RMNH = Naturalis National Natuurhistorisch Museum, Leiden.

\section{Spectracanthicus Nijssen \& Isbrücker, 1987}

Spectracanthicus Nijssen \& Isbrücker, 1987: 93.Type species: Spectracanthicus murinus Nijssen \& Isbrücker, 1987 by original designation and monotypy. Gender masculine.

Oligancistrus Rapp Py-Daniel, 1989: 246. Type species: Chaetostomus punctatissimus Steindachner, 1881 by original designation and monotypy. Gender masculine.

Diagnosis. Spectracanthicus is diagnosed from all other Ancistrini, except Baryancistrus niveatus and B. beggini, and Parancistrus by the presence of an expansion of dorsal-fin membrane connecting the last dorsal-fin ray of to the adipose-fin spine ( $v s$. dorsal fin not expanded and connected to adipose). Spectracanthicus is distinguished from Baryancistrus by having up to 25 teeth on premaxilla ( $v s$. more than 25); and from Parancistrus by having small gill opening, reaching up to $1 / 3$ of cleithrum length ( $v s$. large gill opening, reaching nearly $1 \frac{3}{2}$ of cleithrum length).

\section{Spectracanthicus murinus Nijssen \& Isbrücker, 1987 Figs. 1-2}

Spectracanthicus murinus Nijssen \& Isbrücker, 1987: 94, fig. 1 [type locality: Poça de Pedra, rio Tapajós, Pará, Brazil]. - Burgess, 1989: 445 [citation]. - Eschmeyer, 1998: 1138 [catalog]. - Isbrücker, 2001: 32 [catalog]. - Isbrücker, 2002: 29 [catalog]. - Fisch-Müller, 2003: 395 [catalog]. Ferraris, 2007: 297 [catalog]. - Lujan et al., 2009: 50-56 [citation]. - Camargo et al., 2012:169 [catalog, picture].

Diagnosis. Spectracanthicus murinus is distinguished from its congeners by the non-eversible cheek plate ( $v s$. check plate eversible); the triangular-shaped opercle (vs. bar shaped); presence of three branched anal-fin rays ( $v s$. four); pale (yellow in life) bars on tip of dorsal and caudal fins ( $v s$. bars absent; except in some specimens of $S$. punctatissimus); the frontal forming a small portion of orbit border (less than $1 / 4 v s$. frontal forming a large portion of orbit border); the anterior process of the pterotic-supracleithrum forming the posterior margin of orbit (vs. pterotic-supracleithrum not forming posterior margin of orbit in S. immaculatus or contacting only a small area of orbit posterior margin in remaining species). Spectracanthicus 


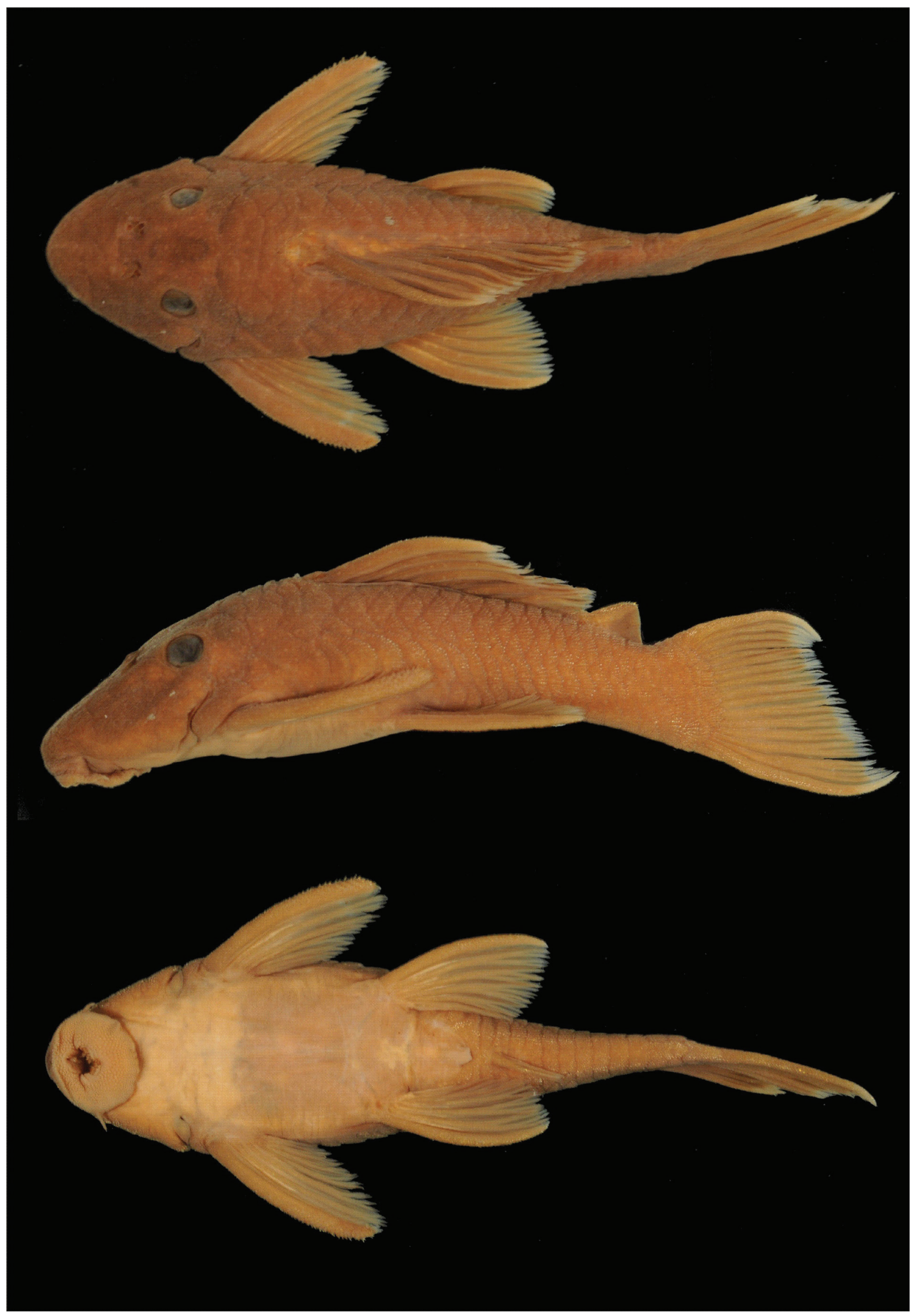

Fig. 1. Spectracanthicus murinus, holotype, MZUSP 22011, 59.7 mm SL, rio Tapajós, Pará State, Brazil. 


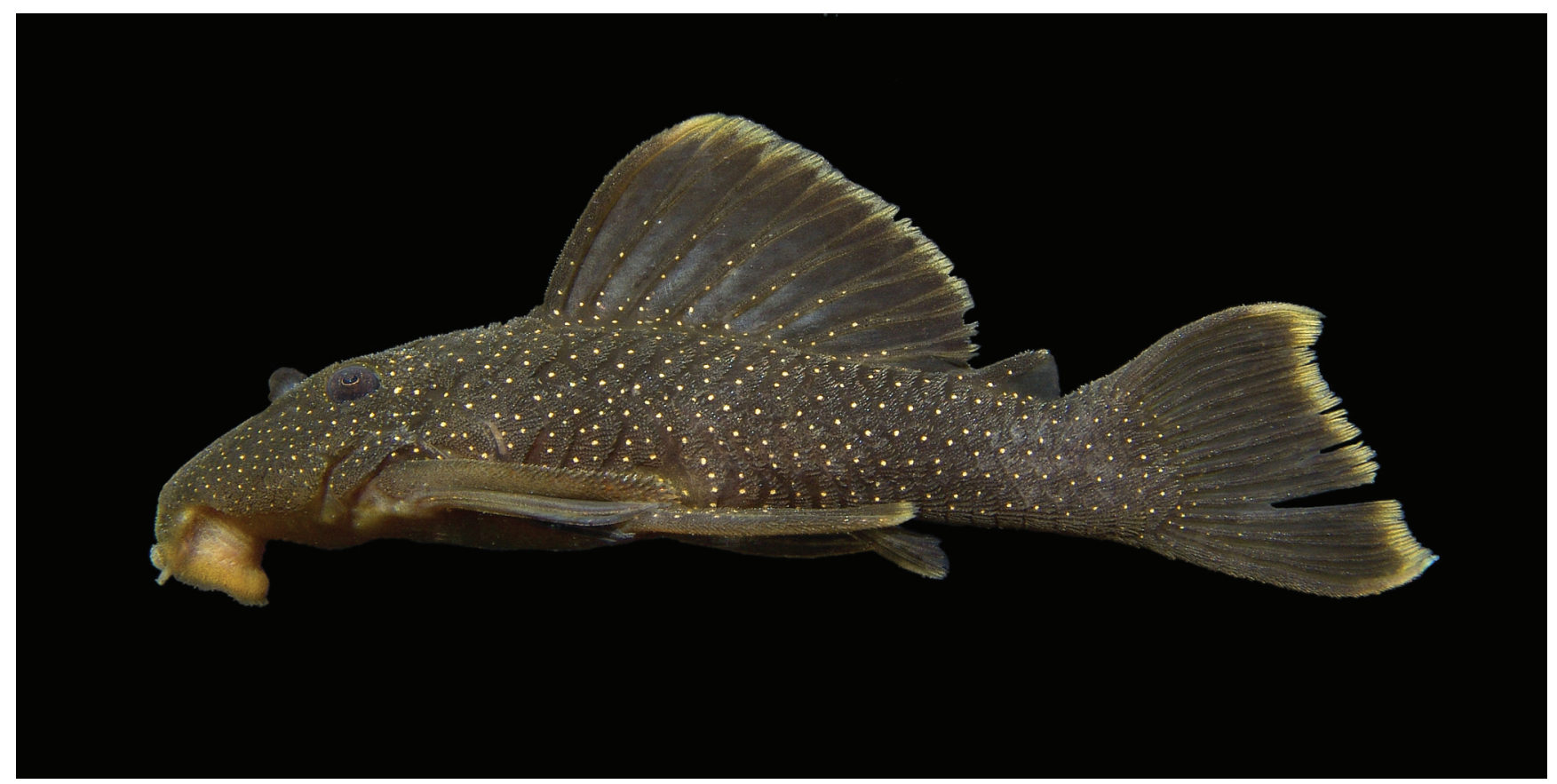

Fig. 2. Color in life of Spectracanthicus murinus (Image by L. M. Sousa).

murinus can be further distinguished from S. immaculatus $\mathrm{n}$. sp. and $S$. zuanoni n. sp. by having pale (yellow in life) small dots on body and fins (vs. dots or spots absent, body and fins dark gray in S. immaculatus; or with large white spots in $S$. zuanoni). It can be also distinguished from $S$. punctatissimus and $S$. tocantinensis $\mathrm{n}$. sp. by the lower counts of premaxillary and dentary teeth, 2 to 3 and 5 respectively ( $v s .3$ to 25 and 8 to 46 in S. punctatissimus; and 5 to 8 and 8-16 in S. tocantinensis).

Description. Morphometric and meristic data are summarized in Table 1. Dorsal profile of body slightly convex from tip of snout to vertical through dorsal-fin origin; concave, nearly straight from that point to caudal-fin origin. Ventral profile of body straight from snout tip to caudal-fin origin. Ventral surface from tip of snout to urogenital papillae lacking plates, except for few small plates at pectoral- and pelvic-fin origins. Greatest body width at pectoral girdle. Head and trunk lacking keels or ridges. Greatest body depth at dorsal-fin origin; lowest at caudal peduncle.

Head wide, pointed anteriorlly; snout and cheek completely covered by numerous small plates, except for small naked area on tip of snout. Snout slightly pointed in dorsal view. Nasal L-shaped, elongate. Frontal short with a slight contact with nares anteriorly and orbit posteriorly Anterior margin of frontal short, reaching posterior margin, or half length, of nare. Parieto-supraoccipital short with posterior edge narrow, lacking crest. Sphenotic short, contacting IO6; lacking conspicuous odontodes. Orbit moderate in size (14.1-33.4\% HL) placed dorsolaterally. Iris with small dorsal flap over pupil. Pteroticsupracleithrum short with few fenestrae; anterior process forming most posterior margin of orbit. Posterior area of pterotic-supracleithrum with one median sized plate.

Mouth moderate in size, nearly as long as wide. Lips large, covered with papillae; size of papillae decreasing towards posterior margin of lower lip; central buccal papilla absent. Upper lip folded over itself. Maxillary barbel short; base of barbel united to lips, with free tip. Lower lip not reaching anterior margin of coracoid. Medial end of premaxillary teeth series curved inwards. Premaxillae (Fig. 3) and dentary narrow and elongate. Dentary strongly curved inwards. Teeth slightly thick, well developed, with long crown and large lateral cusp; its distal edge slightly curved inward. Three to four pairs of well developed predorsal plates. Cheek plates not eversible; without associated hypertrophied odontodes (Fig. 4).

Body covered by five longitudinal series of plates supporting odontodes. Keels absent. Three to four predorsal plates; small azygous predorsal plates sometimes present between predorsal plates. Eight furcate neural spines supporting dorsal fin.

Dorsal-fin rays i,7, pterygiophores located posterior to neural spines of vertebral centra 6-17. Dorsal-fin base very long, its length equivalent to 12 dorsal plates, reaching pre-adipose plate; connected to adipose fin by thick membrane. Dorsal-fin spinelet V-shaped with lock mechanism. Pectoral and pelvic fins well developed, medial portion much expanded relative to base; distal margin rounded. Pectoral-fin rays I,6; unbranched ray covered with conspicuous odontodes. Tip of adpressed pectoral fin almost reaching vertical through medial, unbranched, pelvic-fin ray. Pelvic-fin rays i,5; pelvic-fin spine reaching vertical through anal-fin base when adpressed. Anal-fin rays i,3, 
Table 1. Morphometric and meristic data of Spectracanthicus murinus. Values are given as percents of standard length or head length. $\mathrm{SD}=$ standard deviation.

\begin{tabular}{|c|c|c|c|c|c|c|}
\hline & $\begin{array}{c}\text { Holotype } \\
\text { MZUSP } 22011\end{array}$ & $\mathrm{n}$ & Min & Max & Mean & SD \\
\hline Standard length & 59.7 & 28 & 44.1 & 96.7 & - & - \\
\hline \multicolumn{7}{|c|}{ Percents of Standard Length } \\
\hline Head length & 34.3 & 28 & 33.6 & 41.3 & 35.2 & 1.4 \\
\hline Head depth & 18.1 & 28 & 16.6 & 22.5 & 19.2 & 1.7 \\
\hline Head width & 31.3 & 28 & 26.8 & 31.9 & 29.2 & 1.2 \\
\hline Body depth & 19.4 & 28 & 15.3 & 28.8 & 20.5 & 3.0 \\
\hline Body width at dorsal & 28.3 & 28 & 25.0 & 31.1 & 27.8 & 1.7 \\
\hline Body width at anal & 15.1 & 28 & 12.2 & 20.0 & 15.3 & 1.7 \\
\hline Predorsal length & 43.5 & 28 & 40.8 & 45.9 & 43.7 & 1.1 \\
\hline Postdorsal length & 24.1 & 28 & 22.0 & 63.7 & 51.6 & 15.7 \\
\hline Postanal length & 30.2 & 28 & 28.5 & 38.6 & 32.3 & 2.3 \\
\hline Dorsal-spine length & 26.2 & 28 & 0.0 & 31.7 & 26.9 & 5.5 \\
\hline Pectoral-spine length & 29.7 & 28 & 27.5 & 31.6 & 29.6 & 1.1 \\
\hline Pelvic-spine length & 27.8 & 28 & 25.0 & 30.0 & 27.7 & 1.4 \\
\hline Dorsal-base length & 30.1 & 28 & 29.6 & 40.0 & 34.5 & 2.7 \\
\hline Caudal peduncle depth & 16.4 & 28 & 11.6 & 16.4 & 13.4 & 1.2 \\
\hline \multicolumn{7}{|c|}{ Percents of Head Length } \\
\hline Snout length & 69.7 & 28 & 58.1 & 74.8 & 69.8 & 3.3 \\
\hline Interorbital width & 34.7 & 28 & 31.4 & 39.5 & 36.0 & 1.9 \\
\hline Orbital diameter & 15.1 & 28 & 14.1 & 33.4 & 18.2 & 3.4 \\
\hline \multirow[t]{2}{*}{ Dentary length } & 9.3 & 28 & 4.3 & 9.6 & 8.0 & 1.4 \\
\hline & & & Counts & & Mode & \\
\hline Premaxillary teeth & 3 & 28 & 2 & 3 & 3 & - \\
\hline Dentary teeth & 5 & 28 & 5 & 5 & 5 & - \\
\hline Dorsal-fin rays & $\mathrm{i}+7$ & 28 & $\mathrm{i}+7$ & $i+7$ & $i+7$ & - \\
\hline Pectoral-fin rays & $\mathrm{i}+6$ & 28 & $i+6$ & $\mathrm{i}+6$ & $\mathrm{i}+6$ & - \\
\hline Pelvic-fin rays & $\mathrm{i}+5$ & 28 & $i+5$ & $\mathrm{i}+5$ & $\mathrm{i}+5$ & - \\
\hline Anal-fin rays & $\mathrm{i}+3$ & 28 & $i+3$ & $\mathrm{i}+3$ & $i+3$ & - \\
\hline Caudal-fin rays & $\mathrm{ii}+14$ & 28 & $\mathrm{ii}+14$ & $\mathrm{ii}+14$ & $\mathrm{ii}+14$ & - \\
\hline Lateral line plates & 21 & 28 & 21 & 22 & 22 & - \\
\hline Caudal peduncle plates & 8 & 28 & 7 & 8 & 7 & - \\
\hline
\end{tabular}

located posterior to haemal spines of vertebral centra 1417. Caudal fin i,14,i, truncate; supracaudal plates 7. Usually four procurrent caudal-fin rays. Caudal peduncle strongly deep. Total vertebrae 26, precaudal 8-12. Sixth rib strongly thickened, remaining ribs slender. Infraorbital with 7-8 pores. Infraorbital 4 with little contact with orbit posterior margin. Infraorbital 6 forming only postero-vental part of orbit. Lateral line pores restricted to hypural plate.

Color in alcohol. Dorsal surface of body dark brown with numerous small, yellow dots regularly distributed along head, body and fins. Most specimens with pale, bar-shaped patch lacking chromatophores on caudal-fin distal tip. Ventral surface ochre without dots. Long time preserved specimens may present faint dots along body and fins.

Geographic distribution. Spectracanthicus murinus is known from the rio Tapajós basin, near Itaituba and Santarém, Pará State, Brazil (Fig. 5).

Fisheries and economical importance. Spectracanthicus murinus is an important resource of ornamental fish. It is recognized by local fishermen and aquarists as "bicudo" (snouty). It is usually captured by diving with the aid of a compressor, a typical way to capture ornamental fishes in Itaituba and Santarém regions (Sousa \& Birindelli, 2009). The species citation to rio Xingu basin in Camargo et al., 2012 is probably a misidentification (H. Gimenes Junior, pers. comm.). 

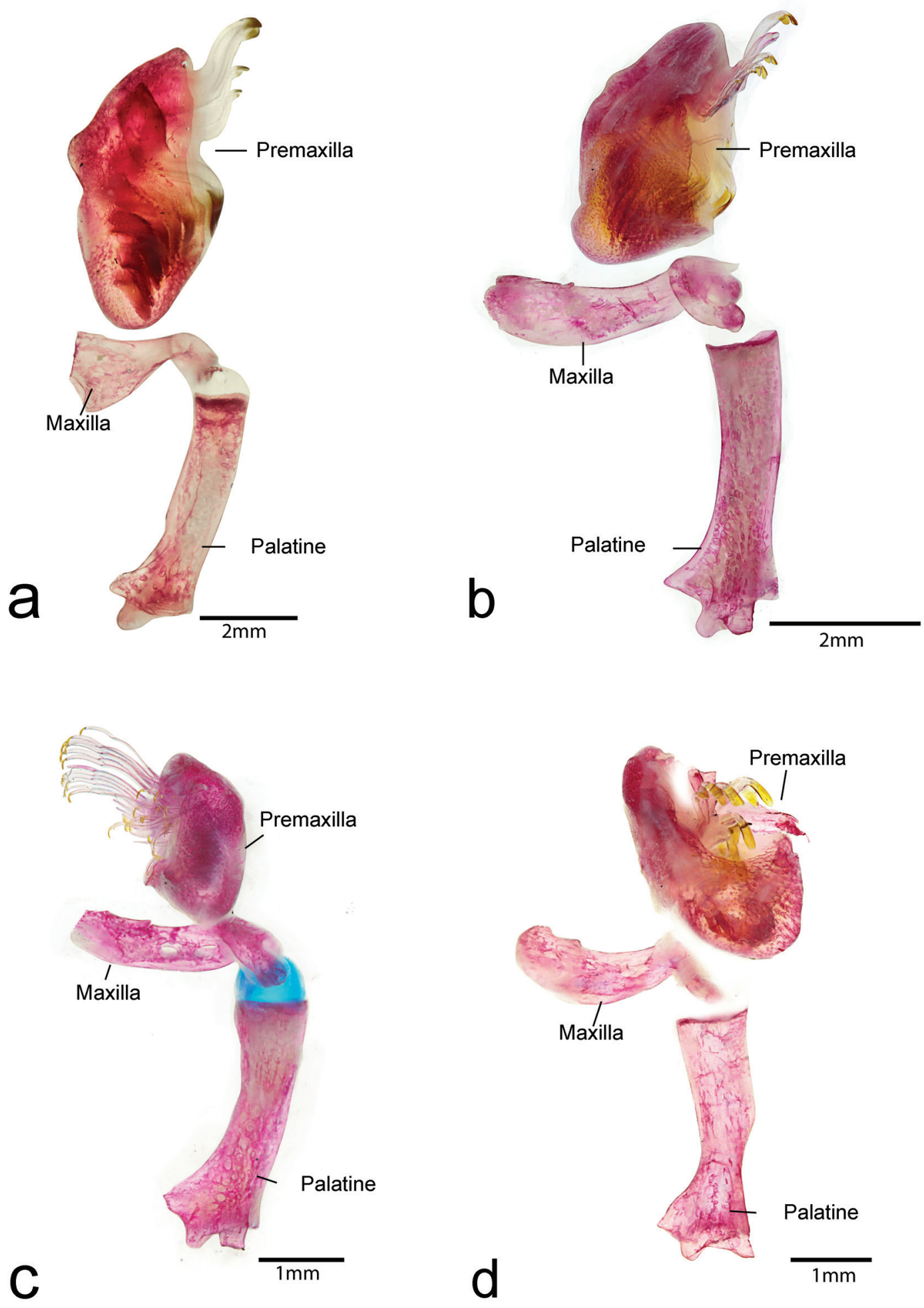

Fig. 3. Palatine, maxillar, and premaxillar in (a) Spectracanthicus murinus, MZUSP 24293, $37.0 \mathrm{~mm}$ SL, (b) Spectracanthicus zuanoni, INPA 3957, $57.0 \mathrm{~mm}$ SL, (c) Spectracanthicus immaculatus, paratype, MZUSP 92617, $58.9 \mathrm{~mm}$ SL and (d) Spectracanthicus tocantinensis, paratype, MZUSP 34265, $65.4 \mathrm{~mm}$ SL. 

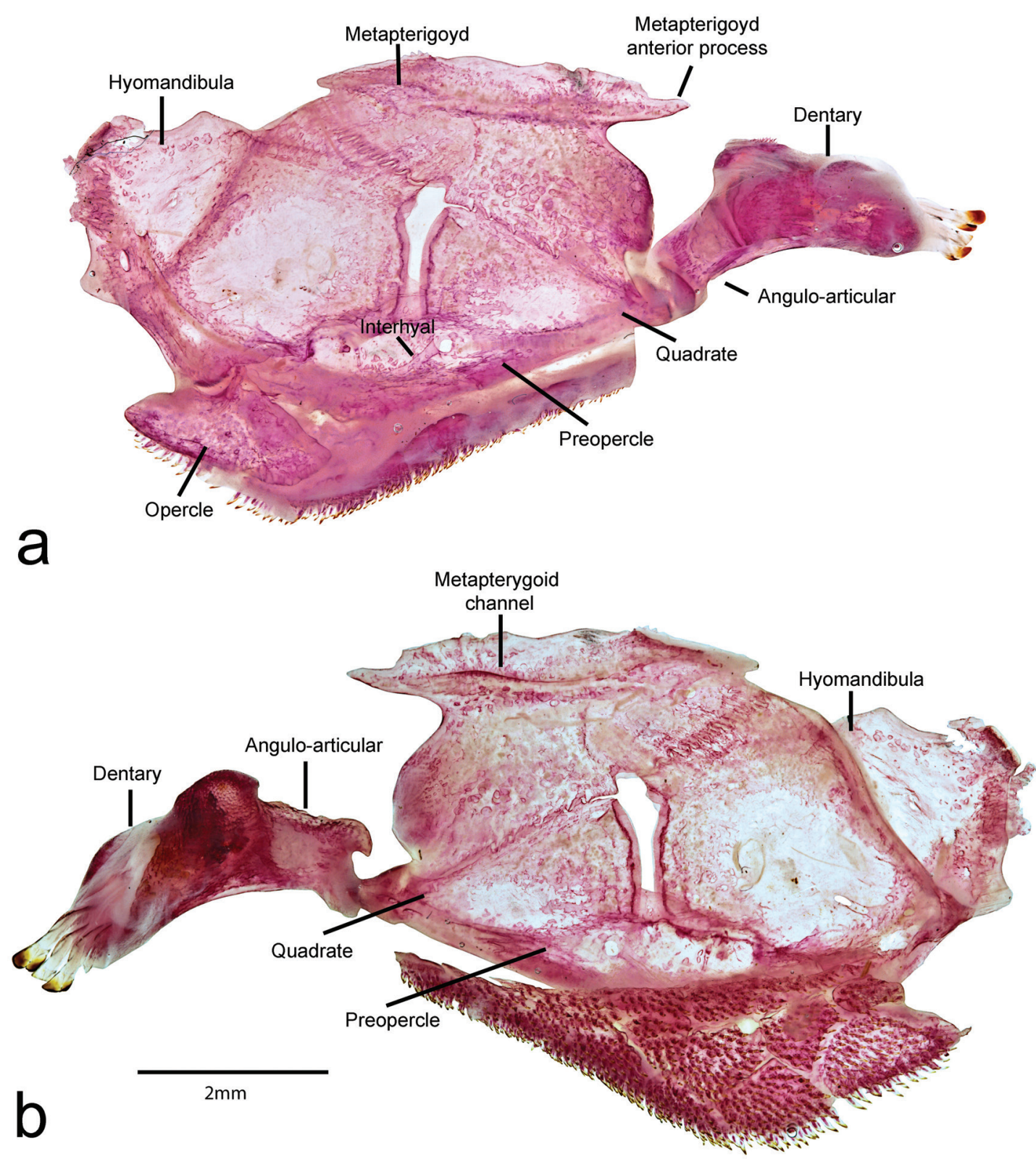

Fig. 4. Suspensorium of Spectracanthicus murinus, MZUSP 24293, $37.0 \mathrm{~mm}$ SL. a. internal view; b. external view. Scale bars = $2 \mathrm{~mm}$. Image by E. Baena.

Material examined. Holotype. MZUSP 22011, 59.7, Brazil, Pará, São Luis, rio Tapajós, $4^{\circ} 27^{\prime} 0.02^{\prime}$ 'S 56 $15^{\circ} 0.00^{\prime \prime}$ W, Expedição Permanente à Amazônia, H. A. Britski et al. Paratypes. All from Brazil, Pará, rio Tapajós: MZUSP 21849, 2, 44.2-58.2 mm SL, São Luís, rio Tapajós, Cachoeira Lombo de Anta, $4^{\circ} 27^{\prime} 60.00^{\prime \prime}$ S 56 $14^{\prime} 60.00^{\prime \prime} \mathrm{W}$, Sep 1970, Expedição Permanente à Amazônia. MZUSP 27633, 1, $45.0 \mathrm{~mm}$ SL, São Luis, rio Tapajós, cachoeira do Maranhãozinho, $4^{\circ} 28^{\prime} 0.00^{\prime}$ S 56 $15^{\circ} 0.00^{\prime \prime} \mathrm{W}$, Expedição Permanente à Amazônia. ZMA 107.878, 2, 55.5-63.6 mm SL, São Luís, rio Tapajós, Cachoeira Lombo de Anta, 4²7'60"S 56¹4'60"W, 6 Oct 1970, Expedição Permanente à Amazônia. ZMA 107.877, 1, 58.6 mm SL, São Luís, poça de pedra no rio Tapajós, 8 Oct 1970. ZMA 107.876, 1, 44.1 mm SL, Cachoeira do Maranhãozinho, rio Tapajós, near São Luis, 4²8'00"S 56¹5’00"W, 06-07 Oct 1970, Expedição Permanente à Amazônia. Non-type. Brazil, Pará, rio Tapajós: INPA 6990,
1, $62.6 \mathrm{~mm}$ SL, Trairão, rio Jamaxim, ilha Terra Preta, 5²7’11"S $55^{\circ} 52^{\prime} 40^{\prime \prime} \mathrm{W}, 20$ Oct 1991, L. Rapp Py-Daniel \& J. Zuanon. INPA 26480, 1, $62.55 \mathrm{~mm} \mathrm{SL}$, Itaituba, obtained from ornamental fish fishermen, 08 Nov 2006, L. M. Sousa \& J. L. Birindelli. INPA 26483, 6, 44.4-84.8 mm SL, Itaituba, donate by fishmen of ornamental fish, 08 Nov 2006, L. M. Sousa \& J. L. Birindelli. INPA 26488, 8, 60.4-96.7 $\mathrm{mm}$ SL, Itaituba, above Itaituba and below cachoeiras de Pimental, 4²1'34"S 056 '10'02”W, 08 Nov 2006, L. M. Sousa \& J. L. Birindelli. INPA 26507, 2, 4.7-57.6 mm SL, Pimental, corredeira do Pajaú e arredores, $4^{\circ} 35^{\prime} 04^{\prime \prime S} 56^{\circ} 15^{\prime} 32^{\prime \prime} \mathrm{W}, 11$ Nov 2006, L. M. Sousa \& J. L. Birindelli. MZUSP 24293, 2, 36.1-39.1 mm SL (1 c\&s, $36.1 \mathrm{~mm}$ SL) São Luís, cachoeira do Maranhãozinho, $4^{\circ} 28^{\prime} \mathrm{S} 56^{\circ} 15^{\prime} \mathrm{W}, 06-07$ Nov 1970, Expedição Permanente à Amazônia. MZUSP 34279, 13, 19.0-46.2 mm SL (1 c\&s, $36.8 \mathrm{~mm} \mathrm{SL}$ ) Pederneiras, below Itaituba, $4^{\circ} 16^{\prime} 41^{\prime \prime} \mathrm{S} 55^{\circ} 59^{\prime} 09^{\prime \prime} \mathrm{W}, 24$ Out 1983, M. Goulding. 


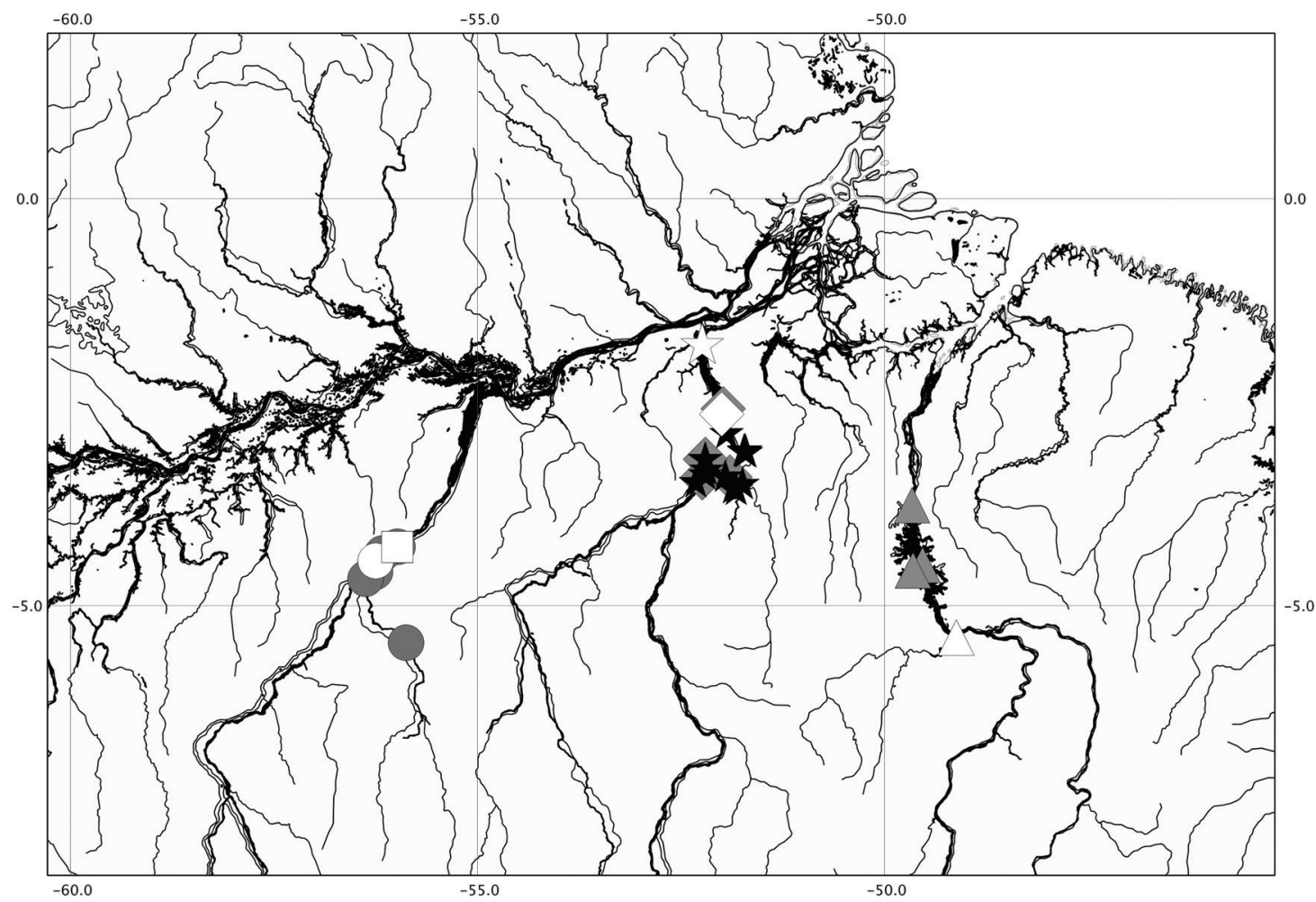

Fig. 5. Distribution map for the species of Spectracanthicus. Circles, S. murinus; stars, S. punctatissimus; squares, S. immaculatus; triangle, S. tocantinensis and diamon, S. zuanoni. White symbols refers to type locality.

\section{Spectracanthicus punctatissimus (Steindachner, 1881)}

Figs. 6-7

Chaetostomus punctatissimus Steindachner, 1881: 119.

[Type locality: east of rio Xingu, Porto de Móz, Pará, Brazil, 14'ㅅ $\left.52^{\circ} 10^{\prime} \mathrm{W}\right]$. - Isbrücker \& Nijssen, 1991: 349 [information about type locality, redescription]. Eschmeyer, 1998: 1398 [catalog]. - Isbrücker, 2001: 26-30 [catalog].

Spectracanthicus punctatissimus. - Lujan et al., 2009:50-56 [citation].

Parancistrus punctatissimus. - Eigenmann \& Eigenmann, 1889: 44 [citation]. - Fowler, 1954: 172 [description]. Burgess, 1989: 435 [atlas]. - Isbrücker, 2002: 23 [catalog]. - Armbruster, 2004: 53 [phylogenetic analysis]. - Ferraris, 2007: 274 [catalog]. - Lujan et al., 2009: 50-56 [citation]. - Isbrücker, 1980: 58 [catalog].

Hypostomus niveatus. - Eigenmann \& Eigenmann, 1889: 44 [citation].

Oligancistrus punctatissimus. - Rapp Py-Daniel, 1989: 236 [description of Oligancistrus]. - Fisch-Müller, 2003: 390 [catalog]. - Ferraris, 2007:274 [catalog]. - Camargo et al., 2012:129 [catalog, picture].
Diagnosis. Spectracanthicus punctatissimus can be distinguished from all congeners by having 12-14 vertebrae from first neural spine not including hypural plate ( $v s .8-11$ in remaining species). It further differs from its congeners (except from $S$. murinus) by having yellowish bars on tip of dorsal and caudal fins; from S. immaculatus and $S$. zuanoni by having small yellowish dots covering body ( $v s$. color pattern uniform, with no dots or large white spots, respectively); and from S. tocantinensis by having the rounded dorsal profile of snout ( $v s$. snout pointed). Spectracanthicus punctatissimus differs from $S$. murinus by presence of a bar-shaped eversible opercle with conspicuous odontodes ( $v s$. triangle-shaped opercle not eversible, without conspicuous odontodes) and by the presence of 4 unbranched anal-fin rays ( $v s .3$ anal-fin unbranched rays).

Description. Morphometric and meristic data summarized in Table 2. Dorsal profile of body slightly convex from tip of snout to vertical through dorsal-fin origin; concave nearly straight from that point to dorsal-fin origin to caudal-fin origin. Ventral profile straight from snout tip to origin of caudal fin. Ventral surface from tip of snout to urogenital papillae lacking plates, except for few small plates at pectoral and pelvic-fins origin. Greatest body width at pectoral girdle. Head and trunk 

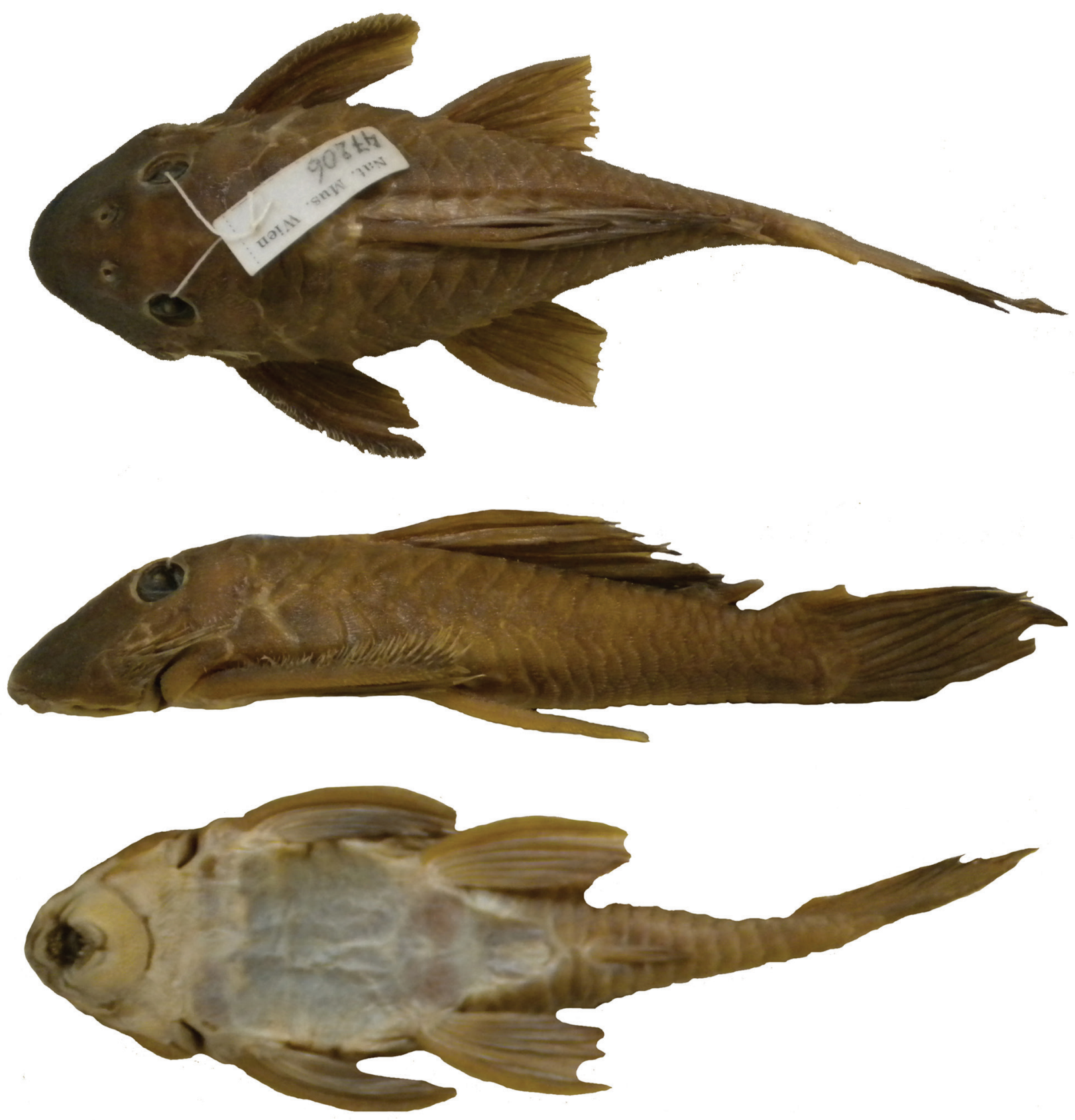

Fig. 6. Spectracanthicus punctatissimus, holotype, NMW 47206, 104.0 mm SL, rio Xingu, Pará State, Brazil.

lacking keels or ridges. Greatest body depth at dorsal-fin origin; lowest at caudal peduncle.

Head wide, convex dorsally; snout and cheeks completely covered by numerous small plates, except for small naked area on tip of snout. Snout rounded in dorsal profile. Nasal elongated, L-shaped. Frontal short with a slight contact with nares anteriorly and orbit posteriorly. Anterior margin of frontal short, reaching posterior margin or half length of nare. Parieto-supraoccipital short with posterior edge narrow, lacking crest. Sphenotic short, without contact with IO6, lacking conspicuous odontodes. Orbit moderate in size (14.4$25.7 \% \mathrm{HL}$ ) placed dorsolaterally. Iris with small dorsal flap over pupil. Pterotic-supracleithrum short with few fenestrae; anterior process forming most posterior margin of orbit. Posterior area of pterotic-supracleithrum with one plate.

Mouth moderate in size, nearly as long as wide. Lips large, covered with papillae; size of papillae decreasing towards posterior margin of lower lip; central buccal papilla absent. Upper lip folded over itself. Maxillary barbel short; base of barbel united to lips with free tip. Lower lip not reaching 


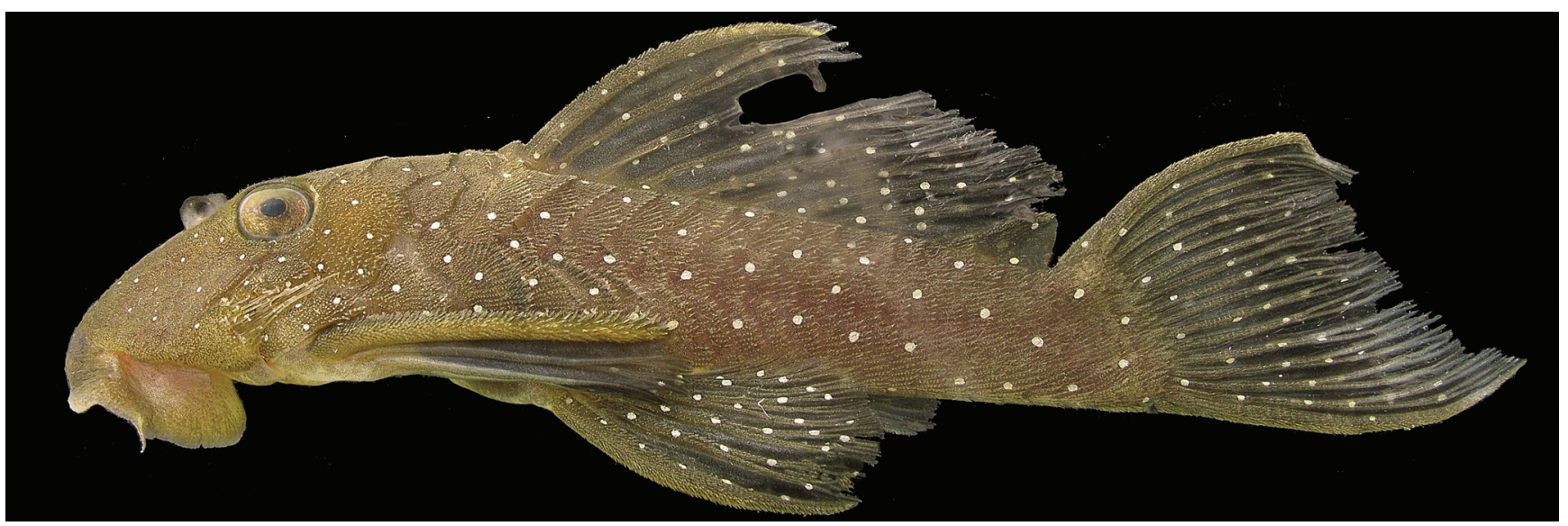

Fig. 7. Color in live of Spectracanthicus punctatissimus. Image by J. Birindelli.

anterior margin of coracoid. Medial end of premaxillary teeth series curved inwards. Premaxillae and dentaries narrow and elongate. Dentaries strongly curved inwards. Teeth medium in size, well developed, with long crown and large lateral cusp, its distal edge slightly curved. Eversible cheek plates with associated hypertrophied odontodes and disposed as unique block connected to opercle, that can be everted to approximately $90^{\circ}$ from head by opercle movements (Fig. 8).

Body covered by five longitudinal series of plates supporting odontodes. Keels absent. Three to four predorsal plates; some small azygous predorsal plates sometimes present. Eight neural bifid spines supporting dorsal fin. Dorsal-fin rays $\mathrm{i}, 7$, located posterior to neural spines of vertebral centra 6-17. Base of dorsal-fin base very long, its length equivalent to 12 dorsal plates, reaching pre-adipose plate and connected to adipose fin by thick membrane. Dorsal-fin spinelet V-shaped with lock mechanism. Pectoral and pelvic fins well developed, medial portion much expanded relative to base; distal margins rounded. Pectoral-fin rays I,6; unbranched ray covered with conspicuous odontodes. Tip of adpressed pectoral fin almost reaching vertical through medial, unbranched, pelvic-fin ray. Pelvic-fin rays i,5; pelvic-fin spine reaching vertical through anal-fin base when adpressed. Anal-fin rays i,4 located posterior to hemal spines of vertebral centra 14-17. Caudal-fin rays i,14,i, truncated; supracaudal plates. Five to six procurrent caudal-fin rays. Caudal peduncle strongly deep in lateral view. Total vertebrae 26, precaudal 8-12. Sixth rib strongly thickened, remaining ribs slender. Infraorbital with 7-8 pores. Infraorbial 4 with little contact with orbit posterior margin. Infraorbital 6 forming only postero-vental part of orbit. Lateral line pores restricted to hypural plate.

Color in alcohol. Dorsal surface of body dark brown to dark gray with numerous, yellow, variable sized dots, from tiny to small, regularly distributed along head, trunk and fins. Density of dots on body variable; pattern apparently independent of body size, however, juvenile specimens usually have fewer dots than adults.
Table 2. Morphometric and meristic data of Spectracanthicus punctatissimus. Values are given as percents of standard length or head length. $\mathrm{SD}=$ standard deviation.

\begin{tabular}{|c|c|c|c|c|c|c|}
\hline & $\begin{array}{c}\text { Holotype } \\
\text { NMW } 47206\end{array}$ & $\mathrm{n}$ & Min & $\operatorname{Max}$ & Mean & SD \\
\hline Standard length & 104.0 & 53 & 33.7 & 119.8 & - & - \\
\hline \multicolumn{7}{|c|}{ Percents of Standard Length } \\
\hline Head length & 34.4 & 53 & 32.8 & 45.3 & 36.5 & 2.1 \\
\hline Head depth & 19.4 & 53 & 15.9 & 27.9 & 20.4 & 2.5 \\
\hline Head width & 29.4 & 53 & 27.2 & 38.0 & 31.1 & 2.3 \\
\hline Body depth & 17.8 & 53 & 15.1 & 29.8 & 20.9 & 3.3 \\
\hline Body width at dorsal & 31.6 & 53 & 26.0 & 41.6 & 30.2 & 2.4 \\
\hline Body width at anal & 14.9 & 53 & 12.1 & 21.1 & 15.9 & 1.9 \\
\hline Predorsal length & 42.6 & 53 & 36.4 & 49.1 & 43.7 & 2.1 \\
\hline Postdorsal length & 31.0 & 53 & 18.7 & 67.5 & 57.3 & 12.9 \\
\hline Postanal length & 32.3 & 53 & 24.9 & 35.8 & 30.6 & 2.4 \\
\hline Dorsal-spine length & 28.1 & 53 & 21.3 & 39.4 & 31.7 & 3.9 \\
\hline Pectoral-spine length & 28.3 & 53 & 27.0 & 35.9 & 31.3 & 2.1 \\
\hline Pelvic-spine length & 28.0 & 53 & 22.9 & 32.4 & 28.7 & 2.1 \\
\hline Dorsal-base length & 28.8 & 53 & 30.2 & 49.3 & 37.9 & 3.4 \\
\hline Caudal peduncle depth & 12.4 & 53 & 11.6 & 16.5 & 13.8 & 1.3 \\
\hline \multicolumn{7}{|c|}{ Percents of Head Length } \\
\hline Snout length & 66.0 & 53 & 53.9 & 76.1 & 62.6 & 4.7 \\
\hline Interorbital width & 37.1 & 53 & 27.4 & 40.4 & 33.4 & 2.8 \\
\hline Orbital diameter & 17.1 & 53 & 14.4 & 25.7 & 20.3 & 2.7 \\
\hline Dentary length & 13.9 & 53 & 8.0 & 16.8 & 11.4 & 2.1 \\
\hline Counts & & & & & Mode & \\
\hline Premaxillary teeth & 14 & 53 & 3 & 25 & 8 & \\
\hline Dentary teeth & 25 & 53 & 8 & 46 & 25 & - \\
\hline Dorsal-fin rays & $\mathrm{i}+7$ & 53 & $\mathrm{i}+7$ & $\mathrm{i}+7$ & $\mathrm{i}+7$ & - \\
\hline Pectoral-fin rays & $\mathrm{i}+6$ & 53 & $\mathrm{i}+6$ & $\mathrm{i}+6$ & $\mathrm{i}+6$ & - \\
\hline Pelvic-fin rays & $\mathrm{i}+5$ & 53 & $\mathrm{i}+5$ & $\mathrm{i}+5$ & $\mathrm{i}+5$ & - \\
\hline Anal-fin rays & $\mathrm{i}+4$ & 53 & $\mathrm{i}+4$ & $\mathrm{i}+4$ & $\mathrm{i}+4$ & - \\
\hline Caudal-fin rays & $\mathrm{ii}+14$ & 53 & $\mathrm{ii}+14$ & $\mathrm{ii}+14$ & $\mathrm{ii}+14$ & - \\
\hline Lateral line plates & 22 & 53 & 20 & 22 & 22 & - \\
\hline $\begin{array}{l}\text { Caudal peduncle } \\
\text { plates }\end{array}$ & 8 & 53 & 7 & 8 & 8 & - \\
\hline
\end{tabular}




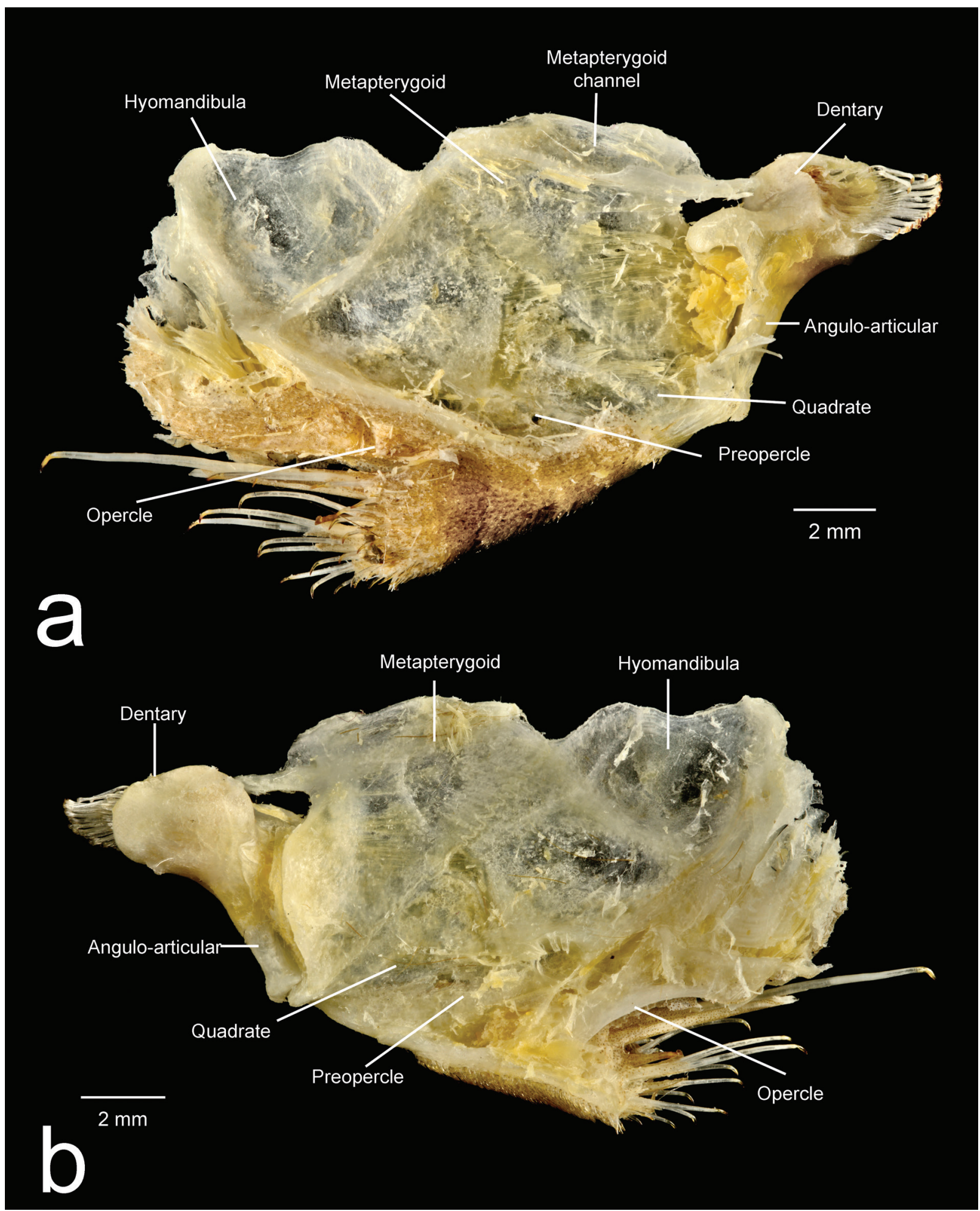

Fig. 8. Suspensorium of Spectracanthicus punctatissimus, MZUSP 108570, $78.2 \mathrm{~mm}$ SL. (a) external view and (b) internal view. Scale bars $=2 \mathrm{~mm}$. Image by E. Baena.

Pale bars on distal tips of dorsal and caudal fins usually present. Irregular white stains rarely observed (called "mutants" specimens by local fishermen). Ventral surface ochre, lacking dots.
Geographic distribution. The species is spread along the rio Xingu basin, near Altamira, Pará, Brazil. It occurs in sympatry with Spectracanthicus zuanoni (Fig. 5). 
Fishery and economical importance. Spectracanthicus punctatissimus is an important resource of ornamental fish. It is also recognized as L016 and L030 (L-number; Schraml \& Schafer, 2004) by aquarists and ornamental fishermen. It is usually captured by diving with aid of a compressor, a typical way to capture ornamental fishes in Altamira, Pará.

Remarks. There is a great variation on premaxilla and dentary teeth counts (3-25 and 8-48, respectively), which seems to be consequently related to a variability of the premaxilla and dentary length/width. Exhaustive examination of specimens were unable to correlate that variation with sexual dimorphism, ontogeny, color pattern or geographical distribution along the river. Regardless of the variation of color and teeth counts, we prefer to sustain S. punctatissimus as single species, since these characteristics are overlapped within known populations.

Material examined. Holotype. NMW 47206, $103.96 \mathrm{~mm} \mathrm{SL}$, rio Xingu, Porto Moz, $1^{\circ} 44^{\prime} 55.10^{\prime \prime S} 52^{\circ} 14^{\prime} 17.04$ ”'W, 23 Ago-Sep 1865, L. Agassiz \& Mr. Vinhas. [Date of collection and collectors information in Higuchi (1996)]. Non-types. All from Brazil, Pará, rio Xingu. INPA 3956, 8, (there is just one in the lot), 64.0 mm SL, cachoeira de Kaituká, Altamira, $3^{\circ} 12^{\prime} 0^{\prime \prime} \mathrm{S} 52^{\circ} 12^{\prime} 0$ "W, 09 Oct 1990, L. Rapp Py-Daniel \& J. Zuanon. INPA 3958 ,4, 20.9$54.2 \mathrm{~mm}$ SL, cachoeira de Kaituká, Altamira, $3^{\circ} 12^{\prime} 0^{\prime \prime} \mathrm{S} 52^{\circ} 12^{\prime} 0^{\prime \prime} \mathrm{W}$, 09 Oct 1990, L. Rapp Py-Daniel \& J. Zuanon. INPA 25786, 42, 3.6-42.7 mm SL, cachoeira do Kaituká, Altamira, 3¹2'0”S $52^{\circ} 12^{\prime} 0$ "W, 09 Oct 1990, L. Rapp Py-Daniel \& J. Zuanon. INPA 29304, 1, 70.9 mm SL, Costa do Junior, Altamira, Oct 1996, J. Zuanon. INPA 31416, 2, 33.7-110.8 mm SL, bedrock in front of

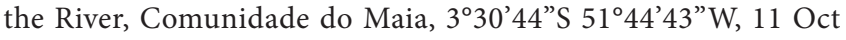
1996, J. Zuanon. INPA 31417, 3, 54.4-119.8 mm SL, bedrock in front of the River, Comunidade do Maia, $3^{\circ} 30^{\prime} 44^{\prime \prime} \mathrm{S} 51^{\circ} 44^{\prime} 43^{\prime \prime} \mathrm{W}$, 09 Nov 2008, L. Rapp Py-Daniel et al. INPA 31424, 3, 87.4110.9 mm SL, Cachoeira do Landi, 335'01"S 51 49'21"W, 08 Nov 2008, L. Rapp Py-Daniel et al. INPA 31446, 2, 46.3-57.4 mm SL, Comunidade do Maia, 331'42” S 52 45’02” W, 09 Nov 2008, L. Rapp Py-Daniel et al. INPA 31453, 24, 34.9-79.2 mm SL, near Altamira, Babaquara, 323'45"S 52 12 ' $16^{\prime \prime}$ W, 07 Nov 2008, L. Rapp Py-Daniel et al. INPA 31461, 9, 36.5-69.7 mm $\mathrm{SL}$, bedrock in front of the river, Itaobinha, Vitória do Xingu, $3^{\circ} 23^{\prime} 45^{\prime \prime}$ S 52 ${ }^{\circ} 12^{\prime} 16^{\prime}$ W, 04 Nov 2008, L. Rapp Py-Daniel et al. INPA 31463, 2, 65.9-96.0 mm SL, Itaboinha, bedrock at the river, Vitória do Xingu, 253’22”S 5156’26”W, 04 Nov 2008, L. Rapp Py-Daniel et al. INPA 31464, 3, 54.4-119.8 mm SL, ilha de Merencio (Pontão), Belo Monte, 306'17”S 5143'33”W, 05 Nov 2008, L. Rapp Py-Daniel et al. INPA 31486, 2, 79.5-114.8 mm SL, Arroz Cru, 325'20"S 5157’22”W, 06 Nov 2008, L. Rapp PyDaniel et al. INPA 31781, 5, 36.6-78.0, Coqueiro, Belo Monte,

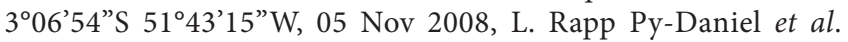
INPA 31784, 9, 33.7-49.1 mm SL, Gorgulho da Rita, Babaquara, 320'14"S 52 11'18”'W, 07 Nov 2008, L. Rapp Py-Daniel et al. INPA 31785, 5, 47.0-119.0 mm SL, Paraná do Rio, Belo Monte,

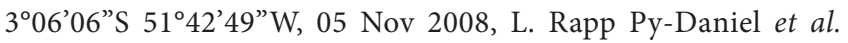
INPA $31782,9,59.4-62.3 \mathrm{~mm}$ SL, Itaboinha, bedrock at the River, Vitória do Xingu, 353’22”S 5156’26”W, 04 Nov 2008, L. Rapp Py-Daniel et al. INPA 31783, 2, 41.3-77.4 mm SL, Gorgulho da Rita, Babaquara, 320'14"S 52¹1'18”, 07 Nov 2008, L. Rapp Py-Daniel et al. INPA 31786, 2, 42.2-50.0 mm SL,
Coqueiro, Belo Monte, 0306'54”S 05143'15”W, 05 Nov 2008, L. Rapp Py-Daniel et al. MHNG 2546.100, 4, 32.84-53.23 mm SL, Balneário de Altamira, 312'32"S 52 12'17”W, 31 Jul-1 Aug 1999, A. Werner. MHNG 2555.14, 16.4 -70.7 mm SL, Altamira, 3'12’32.74"S 52¹2'17.58”W, Jul 1992, A. Werner. MZUSP 107194, 3, 73.3-112.0 mm SL, bedrock, Jericoá, near Mucura fall and the Mazinho farm, Altamira, 324'52"S 51 $44^{\prime} 23^{\prime \prime} \mathrm{W}$, 07 Jun 2010, O. T. Oyakawa, J. Muriel-Cunha, C. C. Chamon, I. Fichberg, L. Rossi \& A. Sawakushi (hereinafter Equipe ECIX ). MZUSP 107206, 55, 35.1-86.1mm SL, Ilha de Babaquara, bedrock, Altamira, 324'11"S 52¹2'27”W, 06 Jul 2010, Equipe ECIX. MZUSP 107211, 6, 36.3-68.7 mm SL, Gorgulho da Rita, Altamira, 320'26”S 52¹1'4"W, 06 Jul 2010, Equipe ECIX. USNM 376496, 3, 72.1-82.7 mm SL, 72.5 km from Senador José Porfírio, $31.5 \mathrm{~km}$ from Porto do Moz, $2^{\circ} 01^{\prime} 59$ ”'S 52¹4'54”W (no information of date and collectors).

\section{Spectracanthicus immaculatus, new species Figs. 9-10}

Holotype. MZUSP 92797, 63.8 mm SL, Brazil, Pará, rio Tapajós, near Itaituba, approximately $4^{\circ} 16^{\prime} 46.56^{\prime \prime}$ S 55 59'5.77'W, 7 Nov 2006, L. M. Sousa \& J. L. Birindelli.

Paratypes. MZUSP 92617, 11, 38.2-82.2 mm SL (1 c\&s, $81.2 \mathrm{~mm}$ SL), Brazil, Pará, rio Tapajós near Itaituba and Pimental, approximately 4¹6’46.56”'S 5559'5.77’'W, 8 Nov 2006, L. M. Sousa \& J. L. Birindelli.

Diagnosis. Spectracanthicus immaculatus can be distinguished from all congeners by its color pattern consisting of a dark gray body, without dots or spots, and by having very slender teeth (vs. with small to mid-sized yellowish dots in S. punctatissimus, S. murinus, and S. tocantinensis; and large white spots in $S$. zuanoni). It further differs from Spectracanthicus punctatissimus and $S$. zuanoni by the pointed snout in dorsal view (vs. snout rounded). Other characters that differs the new species from other congeners are: nasal quadrangular ( $v s$. nasal L-shaped); posterior margin of pterotic-supracleithrum without contact with posterior margin of orbit ( $v s$. with large contact with orbit in S. murinus and small contact in remaining species); cartilage area of basipterygia short ( $v s$. elongate in remaining species, except in S. murinus); anterior fenestrae of cartilage area of basipterygia large in size ( $v s$. small to median size in remaining species, except in S. tocantinensis) (Fig. 11).

Description. Morphometric and meristic data summarized in Table 3. Dorsal profile of body slightly convex from tip of snout to vertical through of dorsal fin; concave, nearly straight from that point to caudal-fin origin. Ventral profile straight from snout tip to origin of caudal fin. Ventral surface from tip of snout to urogenital papillae lacking plates, except for few small plates at pectoral and pelvic-fins origins. Body deep and robust even at caudal peduncle. Head and trunk lacking keels or ridges. Greatest body depth at dorsal-fin origin; lowest at caudal peduncle. 


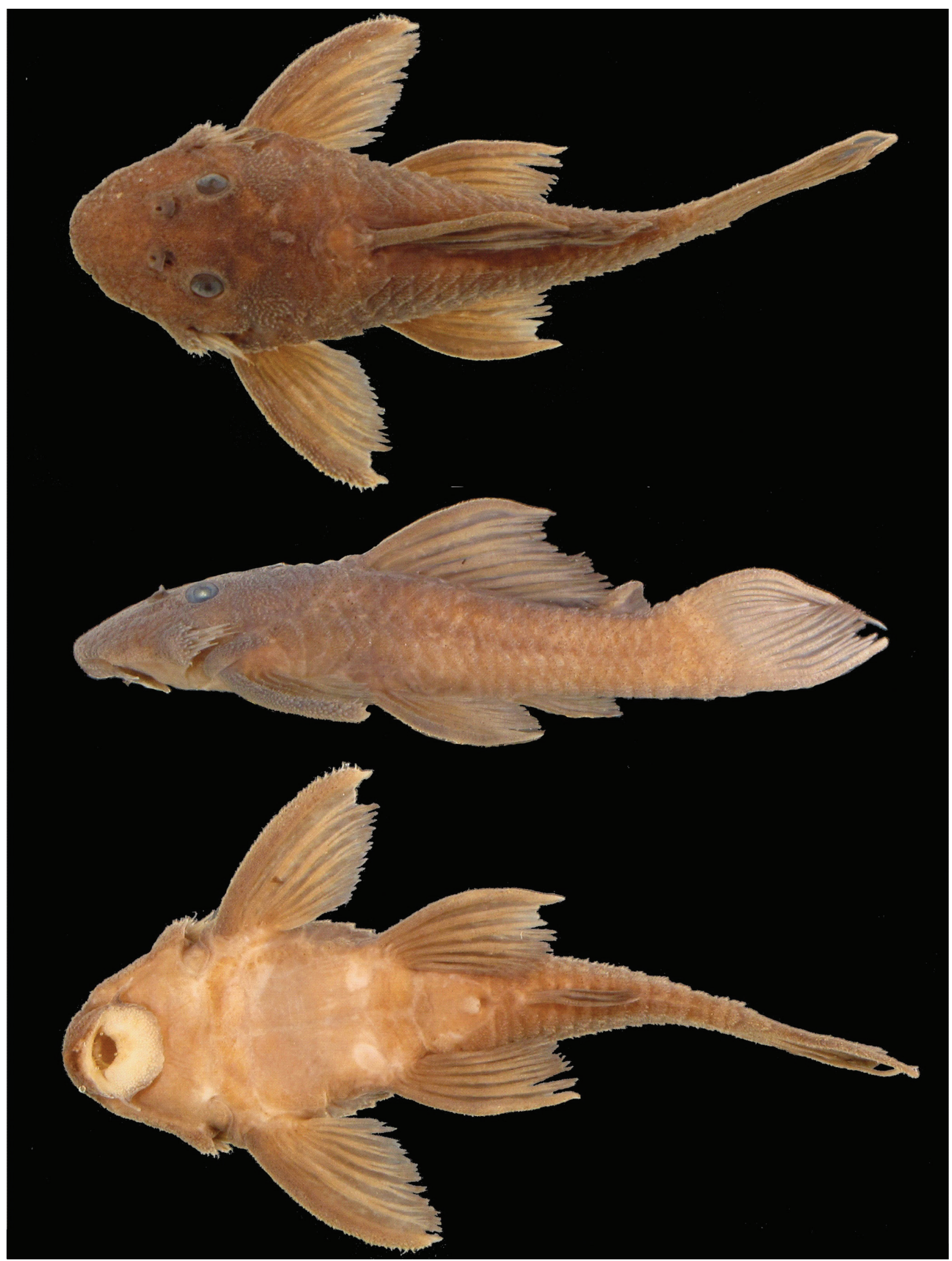

Fig. 9. Spectracanthicus immaculatus, holotype, MZUSP 92797, 64.6 mm SL, rio Tapajós, Pará State, Brazil. 


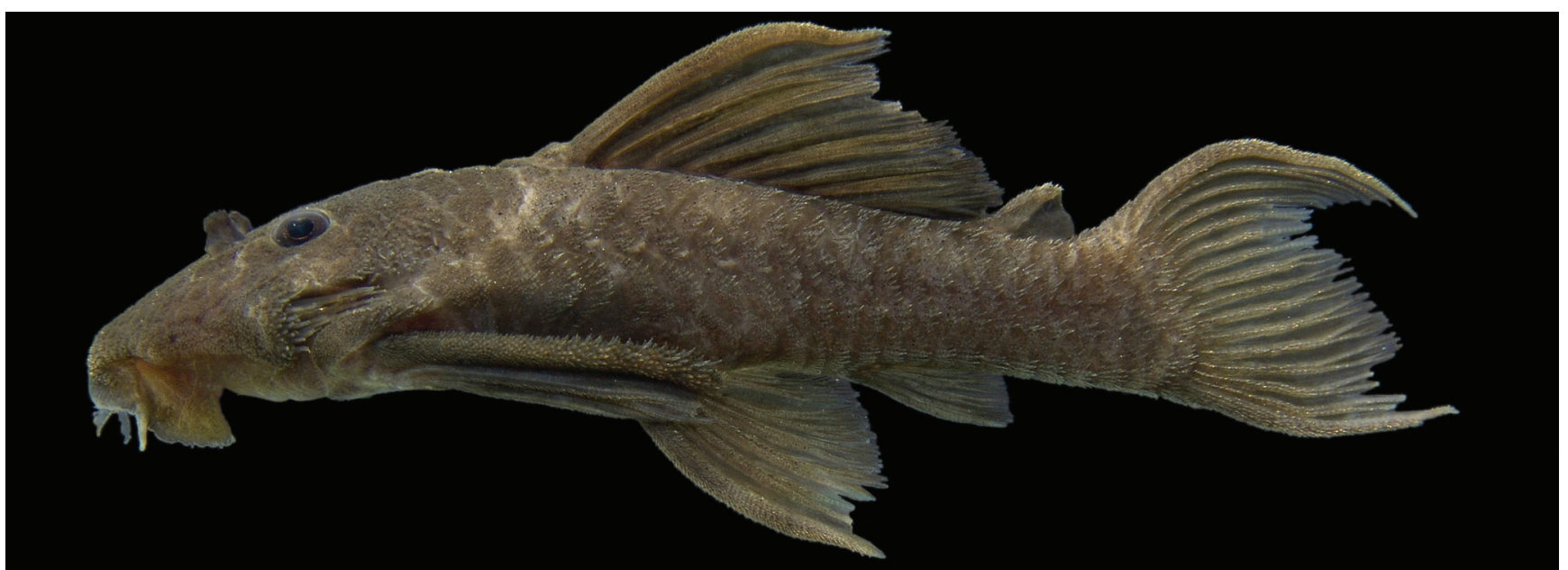

Fig. 10. Color in live of Spectracanthicus immaculatus, paratype, MZUSP 92617, 81.2 mm SL. Image by L. Sousa.
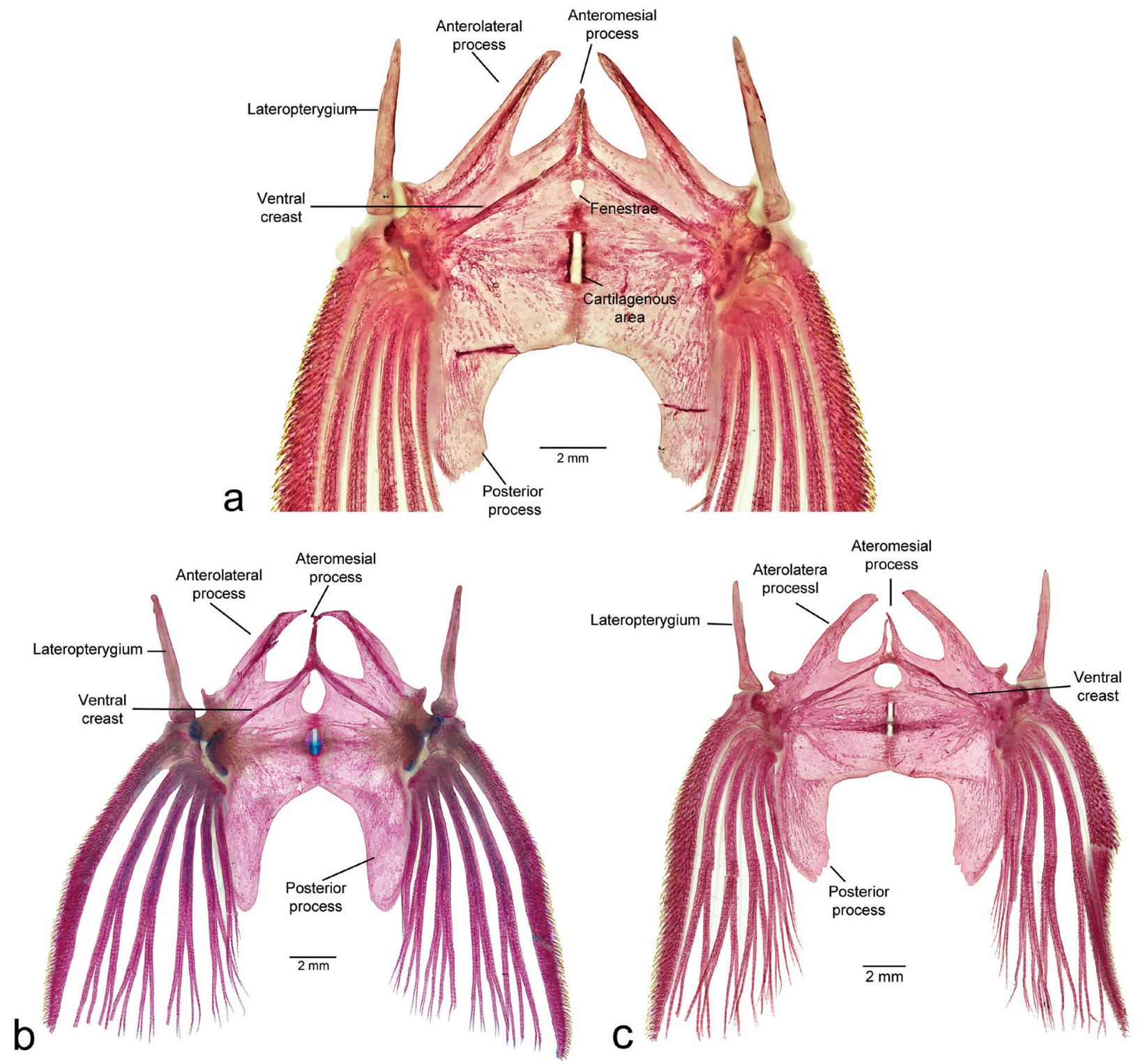

Fig. 11. Basipterygia and pelvic fin of (a) Spectracanthicus murinus, MZUSP 24293, $37.0 \mathrm{~mm}$ SL; (b) S. immaculatus, paratype, MZUSP 92617; $58.9 \mathrm{~mm}$ SL and (c) S. tocantinensis, paratype, MZUSP 34265, 65.4 mm SL. Scale bars =2 mm. Image by E. Baena. 
Table 3. Morphometric and meristic data of Spectracanthicus immaculatus. Values are given as percents of standard length or head length. $\mathrm{SD}=$ standard deviation.

\begin{tabular}{|c|c|c|c|c|c|c|}
\hline & $\begin{array}{c}\text { Holotype } \\
\text { MZUSP } 92797\end{array}$ & $\mathrm{n}$ & Min & Max & Mean & $\mathrm{SD}$ \\
\hline Standard length & 64.6 & 11 & 38.2 & 82.2 & 69.0 & - \\
\hline \multicolumn{7}{|c|}{ Percents of Standard Length } \\
\hline Head length & 23.5 & 11 & 34.1 & 36.2 & 35.4 & 0.7 \\
\hline Head depth & 11.5 & 11 & 16.6 & 29.4 & 20.4 & 3.1 \\
\hline Head width & 20.0 & 11 & 18.6 & 33.8 & 31.0 & 4.1 \\
\hline Body depth & 11.2 & 11 & 16.6 & 23.1 & 20.1 & 1.9 \\
\hline $\begin{array}{l}\text { Body width at } \\
\text { dorsal }\end{array}$ & 18.4 & 11 & 24.9 & 31.4 & 28.3 & 2.1 \\
\hline $\begin{array}{l}\text { Body width at } \\
\text { anal }\end{array}$ & 8.7 & 11 & 12.5 & 16.8 & 14.0 & 1.2 \\
\hline Predorsal length & 27.1 & 11 & 39.8 & 44.3 & 42.1 & 1.0 \\
\hline Postdorsal length & 14.9 & 11 & 20.2 & 36.0 & 25.7 & 3.8 \\
\hline Postanal length & 21.0 & 11 & 24.4 & 32.8 & 28.2 & 2.0 \\
\hline $\begin{array}{l}\text { Dorsal-spine } \\
\text { length }\end{array}$ & 22.5 & 11 & 23.0 & 31.8 & 28.5 & 2.6 \\
\hline $\begin{array}{l}\text { Pectoral-spine } \\
\text { length }\end{array}$ & 21.0 & 11 & 27.8 & 35.1 & 29.3 & 1.9 \\
\hline $\begin{array}{l}\text { Pelvic-spine } \\
\text { length }\end{array}$ & 19.8 & 11 & 24.4 & 27.8 & 26.1 & 0.9 \\
\hline Dorsal-base length & 20.3 & 11 & 27.5 & 34.1 & 31.3 & 2.3 \\
\hline $\begin{array}{l}\text { Caudal peduncle } \\
\text { depth }\end{array}$ & 10.2 & 11 & 12.7 & 14.3 & 13.5 & 0.5 \\
\hline \multicolumn{7}{|c|}{ Percents of Head Length } \\
\hline Snout length & 14.4 & 11 & 55.2 & 63.7 & 60.0 & 2.8 \\
\hline Interorbital width & 7.5 & 11 & 30.0 & 38.2 & 33.4 & 2.1 \\
\hline Orbital diameter & 3.8 & 11 & 13.6 & 16.2 & 14.7 & 0.6 \\
\hline \multirow[t]{2}{*}{ Dentary length } & 2.2 & 11 & 8.1 & 12.8 & 10.9 & 1.5 \\
\hline & Counts & & & & Mode & \\
\hline Premaxillary teeth & 5 & 11 & 6 & 22 & 12 & - \\
\hline Dentary teeth & 7 & 11 & 8 & 30 & 18 & - \\
\hline Dorsal-fin rays & $\mathrm{i}+7$ & 11 & $\mathrm{i}+7$ & $\mathrm{i}+7$ & $\mathrm{i}+7$ & - \\
\hline Pectoral-fin rays & $\mathrm{i}+6$ & 11 & $\mathrm{i}+6$ & $\mathrm{i}+6$ & $\mathrm{i}+6$ & - \\
\hline Pelvic-fin rays & $\mathrm{i}+5$ & 11 & $i+5$ & $i+5$ & $\mathrm{i}+5$ & - \\
\hline Anal-fin rays & $\mathrm{i}+4$ & 11 & $\mathrm{i}+4$ & $\mathrm{i}+4$ & $\mathrm{i}+4$ & - \\
\hline Caudal-fin rays & $\mathrm{ii}+14$ & 11 & $\mathrm{ii}+14$ & $\mathrm{ii}+14$ & $\mathrm{ii}+14$ & - \\
\hline Lateral line plates & 23 & 11 & 21 & 23 & 21 & - \\
\hline $\begin{array}{l}\text { Caudal peduncle } \\
\text { plates }\end{array}$ & 8 & 11 & 7 & 8 & 7 & - \\
\hline
\end{tabular}

Head wide, convex dorsally; snout and cheeks completely covered by numerous small plates, except for small naked area on tip of snout. Snout slightly rounded in dorsal profile. Nasal elongated, L-shaped. Frontal short with a slight contact with nares anteriorly and orbit posteriorly. Anterior margin of frontal short, reaching posterior margin or half of length of nare. Parieto-supraoccipital short with posterior edge narrow, lacking crest. Sphenotic short, without contact with
IO6, lacking conspicuous odontodes. Orbit moderate in size $(13.6-16.2 \% \mathrm{HL})$, placed dorsolaterally in head. Iris with small dorsal flap over pupil. Pterotic-supracleithrum short with few fenestrae; anterior process forming most posterior margin of orbit. Posterior area of pterotic-supracleithrum with one plate.

Mouth moderate in size, nearly as long as wide. Lips large, covered with papillae; size of papillae decreasing towards posterior margin of lower lip; central buccal papilla absent. Upper lip folded over itself. Maxillary barbel short; base of barbel united to lips with free tip. Lower lip not reaching anterior margin of coracoid. Medial end of premaxillary teeth series almost straight. Premaxillae and dentaries narrow and elongate. Dentaries strongly curved inwards. Teeth medium in size, well developed, slender, with long crown and large lateral cusp. Distal edge of teeth slightly curved inward. Eversible cheek plates with associated hypertrophied odontodes and disposed as unique block connected to opercle, that can be everted to approximately $90^{\circ}$ from head by opercle movements (Fig. 12).

Body covered by five longitudinal series of plates supporting odontodes. Keels absent. Three to four predorsal plates; some small azygous predorsal plates sometimes present. Eight neural bifid spines supporting dorsal fin. Dorsal-fin rays i, 7, located posterior to neural spines of vertebral centra 7-17. Dorsal-fin base very long, its length equivalent to 12 dorsal plates, reaching pre-adipose plate and connected to adipose fin by thick membrane. Dorsal-fin spinelet V-shaped with locking mechanism. Pectoral and pelvic fins well developed, medial portion much expanded relative to base; distal margins rounded. Pectoral-fin rays I,6; unbranched ray covered with conspicuous odontodes. Tip of adpressed pectoral fin almost reaching vertical through medial, unbranched, pelvic-fin ray. Pelvic-fin rays i,5; pelvic-fin spine reaching vertical through anal-fin base when adpressed. Anal-fin rays i,4 located posterior to hemal spines of vertebral centra 14-17. Caudal-fin rays i,14,i, truncated; supracaudal plates. Five to six procurrent caudal-fin rays. Caudal peduncle strongly deep in lateral view. Total vertebrae 26 , precaudal $8-12$. Sixth rib strongly thickened, remaining ribs slender. Infraorbital with 7-8 pores. Infraorbital 4 with little contact with orbit by posterior margin. Infraorbital 6 forming only postero-vental part of orbit. Lateral line pores restrict to hypural plate.

Color in alchool. Ground color evenly dark gray to dark brown without dots or spots. Ventral surface ochre to light brown without dots. Dorsal surface of body of live specimens gray.

Distribution. Spectracanthicus immaculatus is known from rio Tapajós basin, near Itaituba and Pimental, Pará State, Brazil.

Etymology. The specific epithet "immaculatus" derives from Latin, meaning unspotted or unstained, in allusion to the coloration pattern of the species, lacking dots or spots. An adjective. 


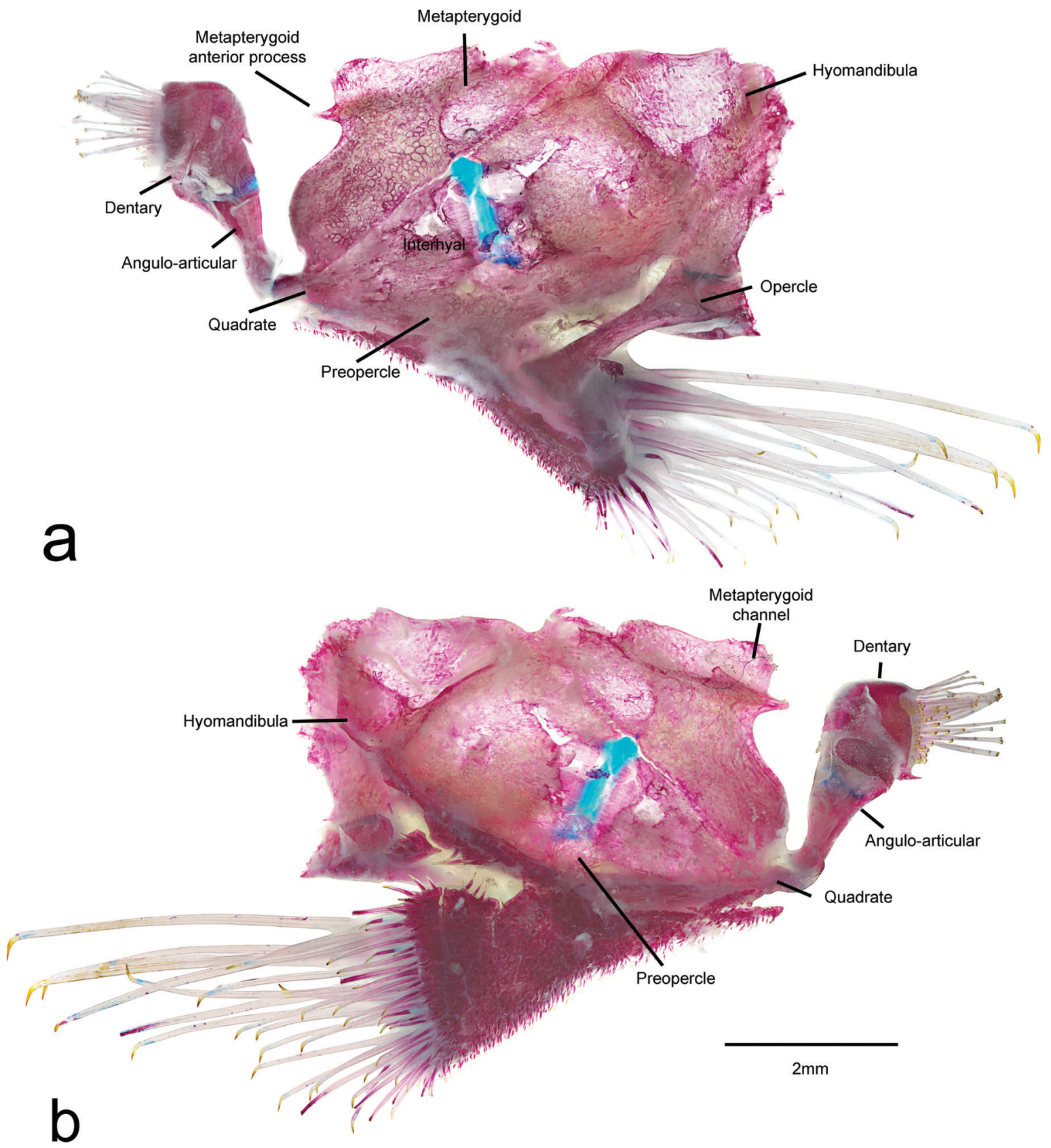

Fig. 12. Suspensorium of Spectracanthicus immaculatus, (a) external view and (b) internal view, paratype, MZUSP 92617 , $58.9 \mathrm{~mm}$ SL. Scale bars $=2 \mathrm{~mm}$. Image by E. Baena.

Fishery and economical importance. Spectracanthicus immaculatus is an important resource of ornamental fish. It is also recognized by local fishermen and aquarists as "naná" or "L363" (L-number; Schraml \& Schafer, 2004; Werner et al. 2005). Like S. murinus, it is also captured by diving with help of a compressor, a typical way of capturing ornamental fishes in Itaituba and Santarém regions (Sousa \& Birindelli, 2009).

Remarks. In Spectracanthicus immaculatus, teeth are extremely slender in relation to its congeners. The number of premaxillary teeth (less than 25 teeth on each) is directly related to the bone shape, which is narrow and elongated. Decrease of teeth counts and narrowing of the premaxillare seems to be a derived condition within the Hypostominae, since the basal species usually have larger and shorter premaxillae supporting more than 25 teeth. Shape of teeth can vary greatly among the Hypostominae and even within Spectracanthicus. In some species of the Hypostomus unicolor group, males in reproductive period acquire elongated, 
slender and unicuspid teeth, which returns to its normal shape, shorter, thicker and with a small cuspid, after this period (Armbruster, 1997). However, this condition in S. immaculatus is not related to sexual dimorphism. On the other hand, in $S$. murinus the teeth are very short and thick, while the teeth have a regular size and density in the remaining species.

\section{Spectracanthicus tocantinensis, new species Fig. 13}

Holotype. MZUSP 110989, 49.5 mm SL; Brazil, Pará, Carreira Comprida, rio Itacaiunas, Tocantins drainage, $5^{\circ} 22^{\prime} \mathrm{S} 49^{\circ} 07^{\prime} \mathrm{W}, \mathrm{M}$. Goulding, 14 Oct 1983.

Paratypes. All from Brazil, Pará, rio Tocantins drainage. INPA 6045, 7, 43.13-76.9 mm SL, poço d'água downstream of Tucuruí Dam, rio Tocantins, 09 Oct 1984, Ichthyology staff, INPA (G. M. Santos \& B. Mérona). INPA 6049, 1, 61.8 mm SL, rio Tocantins, Jatobal, Tucuruí, 05 Jul 1982, Ichthyology staff, INPA. INPA 6050, 1, $62.8 \mathrm{~mm} \mathrm{SL}$, rio Tocantins, Jatobal, Tucuruí, 17 Jul 2008, Ichthyology staff, INPA. INPA 2990, 140, 16.2-92.9 mm SL, rio Tocantins, downstream of Tucuruí Dam, 345'58"S 4940'21'"W, 31 Ago 1984, Ichthyology staff, INPA. INPA 11133, 2, 78.3-86.2 mm SL, rio Tocantins, Tucuruí, 01 Sep 1981, Ichthyology staff, INPA. FMNH 95555, 1, $64.0 \mathrm{~mm}$ SL, lagoon in

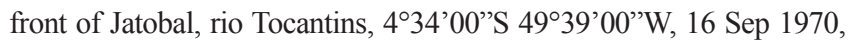
Expedição Permanente à Amazônia. MNRJ 19347, 175, 36.0-85.3 mm SL; rio Tocantins, near Tucuruí, Sep 1984, L. C. Alvarenga. MNRJ 19359, 29, 60.8-82.7 mm SL, rio Tocantins, near Tucuruí, Sep 1984, L. C. Alvarenga. MNRJ 19373, 7, 60.0-63.0 mm SL, rio Tocantins, near Tucurui, Sep 1984, L. C. Alvarenga. MZUSP 24125, 7, 56.4-74.0 $\mathrm{mm}$ SL (1 c\&s, $64.2 \mathrm{~mm} \mathrm{SL}$ ), Jatobal, lagoon in front of Jatobal, rio Tocantins, 49³9'00'W 4³4'00'S, 16 Sep 1970, Expedição permanente à Amazônia. MZUSP 34265, 11, 38.7-72.0mm SL (1 c\&s, 65.4 mm SL), same locality as holotype. MZUSP 39927, 1, $64.5 \mathrm{~mm}$ SL, lagoon in front of Jatobal, rio Tocantins, $4^{\circ} 34^{\prime} 00^{\prime \prime} \mathrm{S} 49^{\circ} 39^{\prime} 00^{\prime \prime} \mathrm{W}, 16$ Sep 1970, Expedição Permanente à Amazônia.

Diagnosis. Spectracanthicus tocantinensis can be diagnosed from its congeners by the infraorbital 4 forming most of the posterior edge of the orbit ( $v s$. IO4 forming a minute portion of orbital rim) and by the large basipterigium fenestrae ( $v S$. medium or small-sized basipterigium fenestrae) (Fig.11). It can be further distinguished from S. immaculatus and S. zuanoni by its color pattern, consisting of small, yellowish dots, and by the presence of thick teeth ( $v$ s. dots lacking in S. immaculatus and large, white spots in $S$. zuanoni; and slender teeth). It is additionally distinguished from $S$. zuanoni by the lower number of dentary teeth (8-16 vs.19-43). Spectracanthicus tocantinensis differs from $S$. murinus by the presence of a bar-shaped, eversible opercle with conspicuous odontodes (vs. triangle shaped opercle not eversible, without conspicuous odontodes) and by the presence of four unbranched anal-fin rays (vs. three unbranched anal-fin rays). The new species further differs from $S$. punctatissimus by the slightly pointed snout in dorsal view (vs. snout rounded in dorsal view).

Description. Morphometric and meristic data are summarized in Table 4. Dorsal profile of body slightly convex from tip of snout to vertical through of dorsal fin; concave, nearly straight from that point to caudal-fin origin. Ventral profile straight from snout tip to origin of caudal fin. Ventral surface from tip of snout to urogenital papillae lacking plates, except for few small plates at pectoral and pelvic-fin origins. Body deep and robust even at caudal peduncle. Head and trunk lacking keels or ridges. Greatest body depth at dorsal-fin origin; lowest at caudal peduncle.

Head wide, convex dorsally; snout and cheeks completely covered by numerous small plates, except for small naked area on tip of snout. Snout slightly rounded in dorsal profile. Nasal elongated, L-shaped. Frontal short with a slight contact with nares anteriorly and orbit posteriorly. Anterior margin of frontal short, reaching posterior margin or half of length of nare. Parieto-supraoccipital short with posterior edge narrow, lacking crest. Sphenotic short, without contact with IO6, lacking conspicuous odontodes. Orbit moderate in size $(15.4-20.3 \% \mathrm{HL})$, placed dorsolaterally in head. Iris with small dorsal flap over pupil. Pterotic-supracleithrum short with few fenestrae; anterior process forming most posterior margin of orbit. Posterior area of pterotic-supracleithrum with one plate.

Mouth moderate in size, nearly as long as wide. Lips large, covered with papillae; size of papillae decreasing towards posterior margin of lower lip; central buccal papilla absent. Upper lip folded over itself. Maxillary barbel short; base of barbel united to lips with free tip. Lower lip not reaching anterior margin of coracoid. Medial end of premaxillary teeth series almost straight. Premaxillae and dentaries narrow and elongate. Dentaries strongly curved inwards. Teeth medium in size, well developed, slender, with long crown and large lateral cusp. Distal edge of teeth slightly curved inward inward. Eversible cheek plates with associated hypertrophied odontodes and disposed as unique block connected to opercle, that can be everted to approximately $90^{\circ}$ from head by opercle movements (Fig. 12).

Body covered by five longitudinal series of plates supporting odontodes. Keels absent. Three to four predorsal plates; some small azygous predorsal plates sometimes present. Eight neural bifid spines supporting dorsal fin. Dorsal-fin rays i,7, located posterior to neural spines of vertebral centra 6-17. Dorsal-fin base very long, its length equivalent to 12 dorsal plates, reaching pre-adipose plate and connected to adipose fin by thick membrane. Dorsal-fin spinelet V-shaped with locking mechanism. Pectoral and pelvic fins well developed, medial portion much expanded relative to its base; distal margins rounded. Pectoral-fin rays I,6; unbranched ray covered with 
conspicuous odontodes. Tip of adpressed pectoral fin almost reaching vertical through medial, unbranched, pelvic-fin ray. Pelvic-fin rays i,5; pelvic-fin spine reaching vertical through anal-fin base when adpressed. Anal-fin rays i,4 located posterior to hemal spines of vertebral centra 14-17. Caudalfin rays i,14,i, truncated; seven supracaudal plates. Five to six procurrent caudal-fin rays. Caudal peduncle strongly deep in lateral view. Total vertebrae 26, precaudal 8-12. Ribs slender, except strong sixth rib. Infraorbital with 7-8 pores. Infraorbital 4 with great contact with orbit by posterior margin. Infraorbital 6 formed just postero-vental part of orbit. Lateral line pores restrict to hypural plate.
Color in alcohol. Dorsal surface of body and fins dark brown with small to median-sized yellowish dots regularly distributed along head, trunk and fins. Body dots sparced and usually fewer in juveniles. Ventral surface light tan without dots.

Geographic distribution. Spectracanthicus tocantinensis is known from the lower rio Tocantins, near Tucuruí and Jatobal, Pará, Brazil (Fig. 5).

Etymology. The specific epithet "tocantinensis" is in allusion to the type locality of the new species, the rio Tocantins. An adjective.

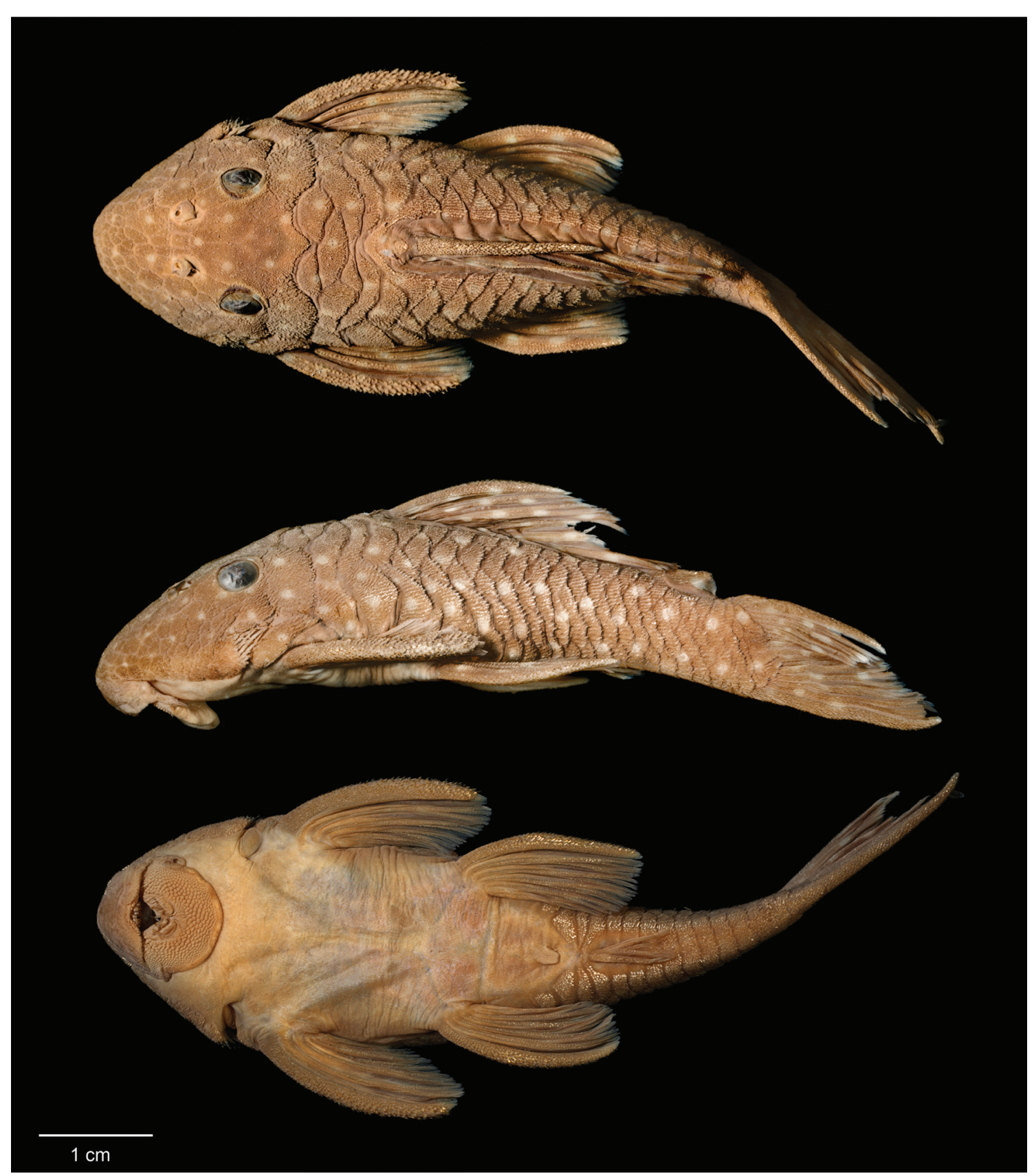

Fig. 13. Spectracanthicus tocantinensis, holotype, MZUSP 110989, 56.4 mm SL, rio Tocantins, Pará State, Brazil. Image by E. Baena. 
Table 4. Morphometric and meristic data of Spectracanthicus tocantinensis. Values are given as percents of standard length or head length. $\mathrm{SD}=$ standard deviation.

\begin{tabular}{|c|c|c|c|c|c|c|}
\hline & $\begin{array}{c}\text { Holotype } \\
\text { MZUSP } \\
110989\end{array}$ & $\mathrm{n}$ & Min & Max & Mean & SD \\
\hline Standard length & 56.4 & 31 & 57.7 & 93.3 & 72.5 & $8.7-$ \\
\hline \multicolumn{7}{|c|}{ Percents of Standard Length } \\
\hline Head length & 20.7 & 31 & 32.4 & 37.3 & 35.4 & 1.4 \\
\hline Head depth & 11.2 & 31 & 17.4 & 28.1 & 20.5 & 2.2 \\
\hline Head width & 18.6 & 31 & 30.2 & 34.8 & 32.0 & 1.2 \\
\hline Body depth & 11.2 & 31 & 17.3 & 26.4 & 20.6 & 2.3 \\
\hline Body width at dorsal & 15.6 & 31 & 25.9 & 31.9 & 28.1 & 1.5 \\
\hline Body width at anal & 8.3 & 31 & 14.6 & 19.1 & 16.1 & 1.3 \\
\hline Predorsal length & 24.9 & 31 & 42.3 & 48.8 & 43.9 & 1.5 \\
\hline Postdorsal length & 13.5 & 31 & 16.3 & 28.0 & 22.1 & 2.9 \\
\hline Postanal length & 15.5 & 31 & 25.1 & 35.4 & 29.6 & 3.2 \\
\hline Dorsal-spine length & 15.7 & 31 & 25.5 & 31.8 & 28.7 & 1.7 \\
\hline Pectoral-spine length & 16.6 & 31 & 27.3 & 31.9 & 29.4 & 1.2 \\
\hline Pelvic-spine length & 15.8 & 31 & 24.2 & 28.7 & 26.8 & 1.2 \\
\hline Dorsal-base length & 17.5 & 31 & 30.6 & 36.2 & 33.3 & 1.7 \\
\hline Caudal peduncle depth & 8.2 & 31 & 14.0 & 18.0 & 14.9 & 1.0 \\
\hline \multicolumn{7}{|c|}{ Percents of Head Length } \\
\hline Snout length & 12.9 & 31 & 59.3 & 70.8 & 63.5 & 2.6 \\
\hline Interorbital width & 7.0 & 31 & 31.7 & 37.7 & 34.8 & 1.4 \\
\hline Orbital diameter & 3.6 & 31 & 15.4 & 20.3 & 17.9 & 1.2 \\
\hline Dentary length & 1.8 & 31 & 8.6 & 15.8 & 11.5 & 2.1 \\
\hline \multicolumn{4}{|c|}{ Counts } & \multicolumn{3}{|c|}{ Mode } \\
\hline Premaxillary teeth & 7 & 31 & 5 & 8 & 6 & - \\
\hline Dentary teeth & 10 & 31 & 8 & 16 & 12 & - \\
\hline Dorsal-fin rays & $i+7$ & 31 & $\mathrm{i}+7$ & $\mathrm{i}+7$ & $\mathrm{i}+7$ & - \\
\hline Pectoral-fin rays & $i+6$ & 31 & $i+6$ & $\mathrm{i}+6$ & $\mathrm{i}+6$ & - \\
\hline Pelvic-fin rays & $i+5$ & 31 & $i+5$ & $\mathrm{i}+5$ & $\mathrm{i}+5$ & - \\
\hline Anal-fin rays & $i+4$ & 31 & $i+4$ & $\mathrm{i}+4$ & $i+4$ & - \\
\hline Caudal-fin rays & $\mathrm{ii}+14$ & 31 & $\mathrm{ii}+14$ & $\mathrm{ii}+14$ & $\mathrm{ii}+14$ & - \\
\hline Lateral line plates & 23 & 31 & 20 & 24 & 23 & - \\
\hline Caudal peduncle plates & 7 & 31 & 7 & 8 & 7 & - \\
\hline
\end{tabular}

\section{Spectracanthicus zuanoni, new species Figs. 14-15}

Oligancistrus sp. - Werner et al., 2005: 23 [catalog; picture]. Oligancistrus n. sp. 2. - Camargo et al., 2012: 131 [catalog; picture].

Holotype. INPA 25874, $122.4 \mathrm{~mm}$ SL, ilha do Sr. Izaltino, rio Xingu, Altamira, Pará, Brazil, 3¹6'21'S 52¹2'7’W, J. Zuanon, 14 Sep 1997.

Paratypes. All from Brazil, Pará, rio Xingu. INPA 4031, 2, 78.2127.9 mm SL, $1^{\circ} 30^{\prime} 0^{\prime}$ 'S 51 ${ }^{\circ} 53^{\prime} 0^{\prime \prime} \mathrm{W}, 05$ Oct 1990, L. Rapp Py-Daniel \& J. Zuanon. INPA 4147, 1, $84.9 \mathrm{~mm}$ SL, ilha de Babaquara, $1^{\circ} 30^{\prime} 0^{\prime \prime}$ 'S
5153’0”W, 05 Oct 1990, J. Zuanon. INPA 25874, 3, 69.9-126.2 mm SL, ilha do Sr. Izaltino, bedrock beside the island (left margim), 1'30'0"S 51 53'0' W, 14 Sep 1997, J. Zuanon. INPA 25876, 1, 123.1 mm SL, 1³0'0”S 51 ${ }^{\circ} 53^{\prime} 0$ ”'W. INPA 25877, 2, 70.6-129.3 mm SL, ilha do Sr. Izaltino, left margin, $1^{\circ} 30^{\prime} 0^{\prime \prime S} 51^{\circ} 53^{\prime} 0^{\prime \prime} \mathrm{W}, 14$ Sep 1997, J. Zuanon. INPA 25878, 1, $107.3 \mathrm{~mm} \mathrm{SL}, 1^{\circ} 30^{\prime} 0^{\prime}$ 'S $51^{\circ} 53^{\prime} 0^{\prime}$ 'W. INPA 25879, 2, 76.9-112.8 $\mathrm{mm} \mathrm{SL}$, ilha do Sr. Izaltino, bedrock beside the island (left margim), 1³0'0”S 51 $53^{\prime}$ '0'W, 14 Sep 1997, J. Zuanon. INPA 25881, 1, $93.2 \mathrm{~mm}$ SL, ilha do Bananal, Senador José Porfírio, 08 Sep 1997, J. Zuanon. INPA 25882, 2, 55.9-82.8 mm SL, corredeiras do Arini, $1^{\circ} 30^{\prime} 0^{\prime}$ 'S, 51 53'0'W, 07 Sep 1997, J. Zuanon. MZUSP 107200, 3, 59.4-86.1 mm SL, bedrock near Jericoá, near Mucura fall and above Mazinho's farm, Altamira, 324'52"S 51 ${ }^{\circ} 44^{\prime} 23^{\prime}$ "W, 07 Jun 2010, Equipe ECIX (O. T. Oyakawa, J. Muriel-Cunha, C. C. Chamon, I. Fichberg, L. Rossi \& A. Sawakushi). MZUSP 107202, 3, 37.8-95.3 mm SL, Gorgulho da Rita, Altamira, 320'26"S 52 $11^{\prime} 4^{\prime \prime}$ 'W, 06 Jul 2010, Equipe ECIX. MZUSP 107207, 17, 41.3-98.1 mm SL, ilha de Babaquara, bedrock, Altamira, $3^{\circ} 24^{\prime} 10^{\prime \prime} \mathrm{S} 52^{\circ} 12^{\prime} 27^{\prime \prime} \mathrm{W}, 06 \mathrm{Jul}$ 2010, Equipe ECIX.

Non-Types. All from Brazil, Pará, rio Xingu. INPA 3957, 5, 20.1-58.8 mm SL, cachoeira de Baituká, $1^{\circ} 30^{\prime} 0^{\prime}$ 'S 51 ${ }^{\circ} 53^{\prime} 0$ ”'W, 09 Oct 1990, L. Rapp Py-Daniel \& J. Zuanon. INPA 3966, 2, 67.196.6 mm SL, Praia do Pedral, 1³0'0”S 51 ${ }^{\circ} 53^{\prime} 0^{\prime \prime}$ 'W 07 Oct 1990, L. Rapp Py-Daniel \& J. Zuanon. INPA 28545, 2, 27.5-23.8 mm

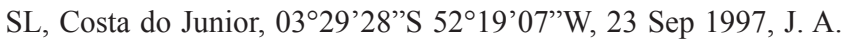
Zuanon. INPA 31411, 4, 78.4-92.9 mm SL, bedrock in front of the River, Comunidade do Maia, 03³0'44”S 5144'43”W, 09 Nov 2008, L. Rapp Py-Daniel et al. INPA 31422, 3, 59.3-111.3 mm SL,

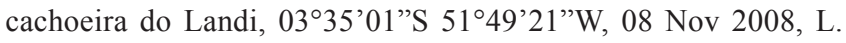
Rapp Py-Daniel et al. INPA 31454, 2, 47.6-71.1 mm SL, Gorgulho da Rita, 0320'14"S 52 11'18”'W, 07 Nov 2008, L. Rapp Py-Daniel et al. INPA 31455, 6, 41.4-72.4 mm SL, Babaquara, 03²3'45"S $52^{\circ} 12^{\prime} 16$ ”'W, 07 Nov 2008, L. Rapp Py-Daniel et al. INPA 31460, 8, 35.3-89.8 mm SL, Itaboinha, bedrock, Vitória do Xingu, 03 ${ }^{\circ} 53^{\prime 2} 22^{\prime \prime} \mathrm{S}$ 51 $56^{\circ} 26^{\prime}$ 'W, 04 Nov 2008, L. Rapp Py-Daniel et al. INPA 31480, 11, 53.1-126.8 mm SL, Arroz Cru, 03²5'20”'S 51 '57'22”'W, 06 Nov 2008, L. Rapp Py-Daniel et al. INPA 31775, 1, $113.0 \mathrm{~mm}$ SL, ilha do Davi, Altamira, 0332'39'S 51 '57'29”'W, 01 Nov 2008, L. Rapp Py-Daniel et al. INPA 31794, 2, 50.5-54.0 mm SL, Belo Monte, 0306'54"S 5143'15”W, 05 Nov 2008, L. Rapp Py-Daniel et al. MHNG 2578.027, 1, $81.8 \mathrm{~mm}$ SL, Altamira (?), imported from Belém, D. Fisher. MHNG 2.680.014, 1, $79.9 \mathrm{~mm}$ SL, aquarium import, R. Covain. MHNG 2684.026, 2, 62.2-66.6 mm SL, aquarium import, R. Covain.

Diagnosis. Spectracanthicus zuanoni can be diagnosed from all other congeners by its color pattern consisting of large, white spots (vs. small yellowish dots in S. murinus, $S$. punctatissimus, and $S$. tocantinensis, and dark gray lacking dots in S. immaculatus). It also differs from congeners, except S. murinus, by the larger orbital diameter (up to $29.2 \%$ of HL 


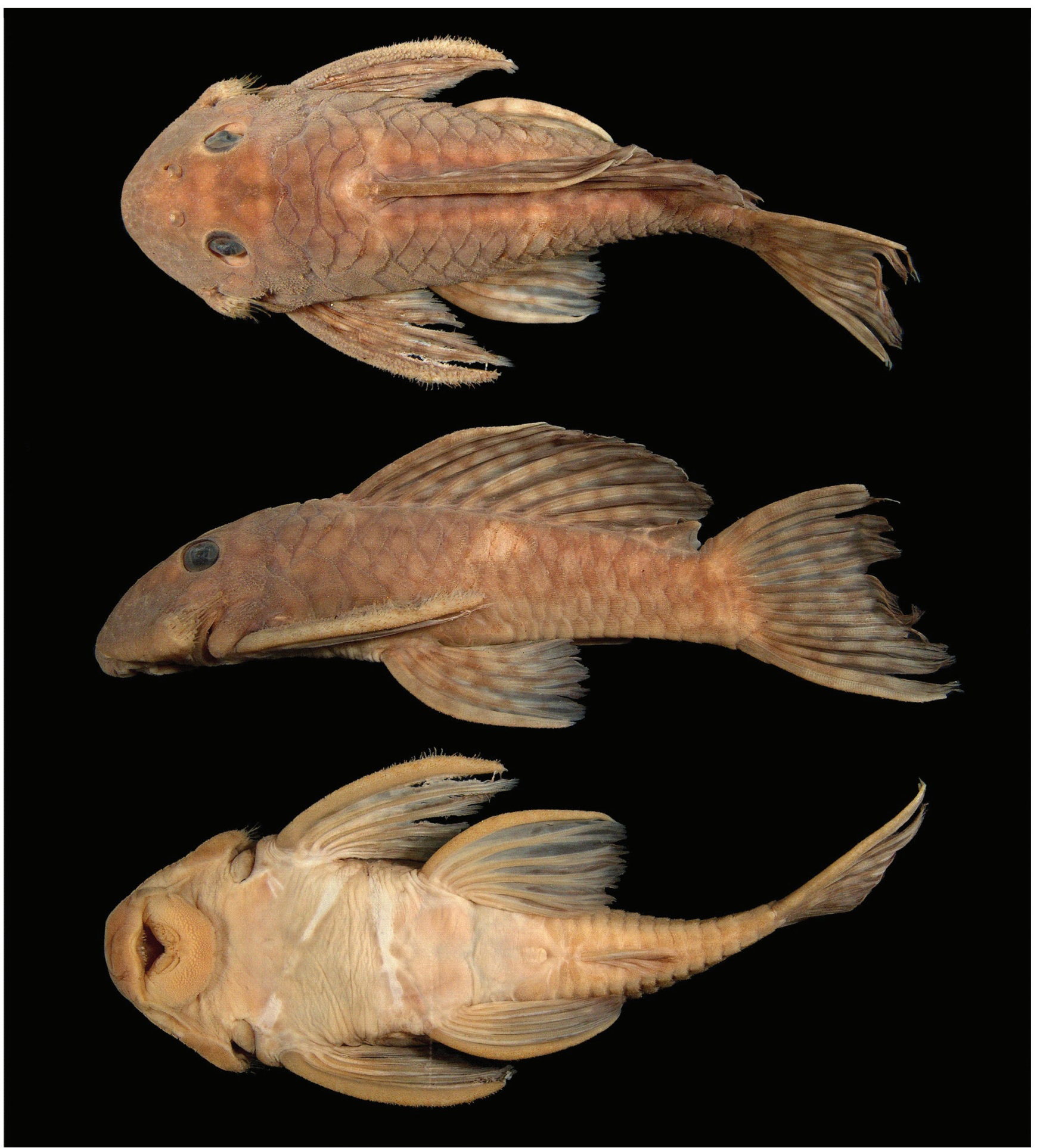

Fig. 14. Spectracanthicus zuanoni, holotype, INPA 25874, 122.5 mm SL, rio Xingu, Pará State, Brazil.

vs. up to $25.7 \%$ in S. punctatissimus, $20.3 \%$ in S. tocantinensis, $16.2 \%$ in S. immaculatus). It further differs from S. murinus by the rounded dorsal view of the snout, the bar-shaped, eversible opercle with conspicuous odontodes, and the presence of four unbranched anal-fin rays ( $v s$. snout slightly pointed; opercle triangle-shaped, not eversible, lacking conspicuous odontodes; three anal-fin unbranched rays). From $S$. tocantinensis it differs by present high counts of dentary teeth (19-43 vs. 8-16) and by IO4 forming just a small area of orbit ( $v s$. IO4 forming posterior edge of orbit almost totally).

Description. Morphometric and meristic data summarized in Table 5. Dorsal profile of body slightly convex from tip of snout to vertical through of dorsal fin; concave, nearly straight 


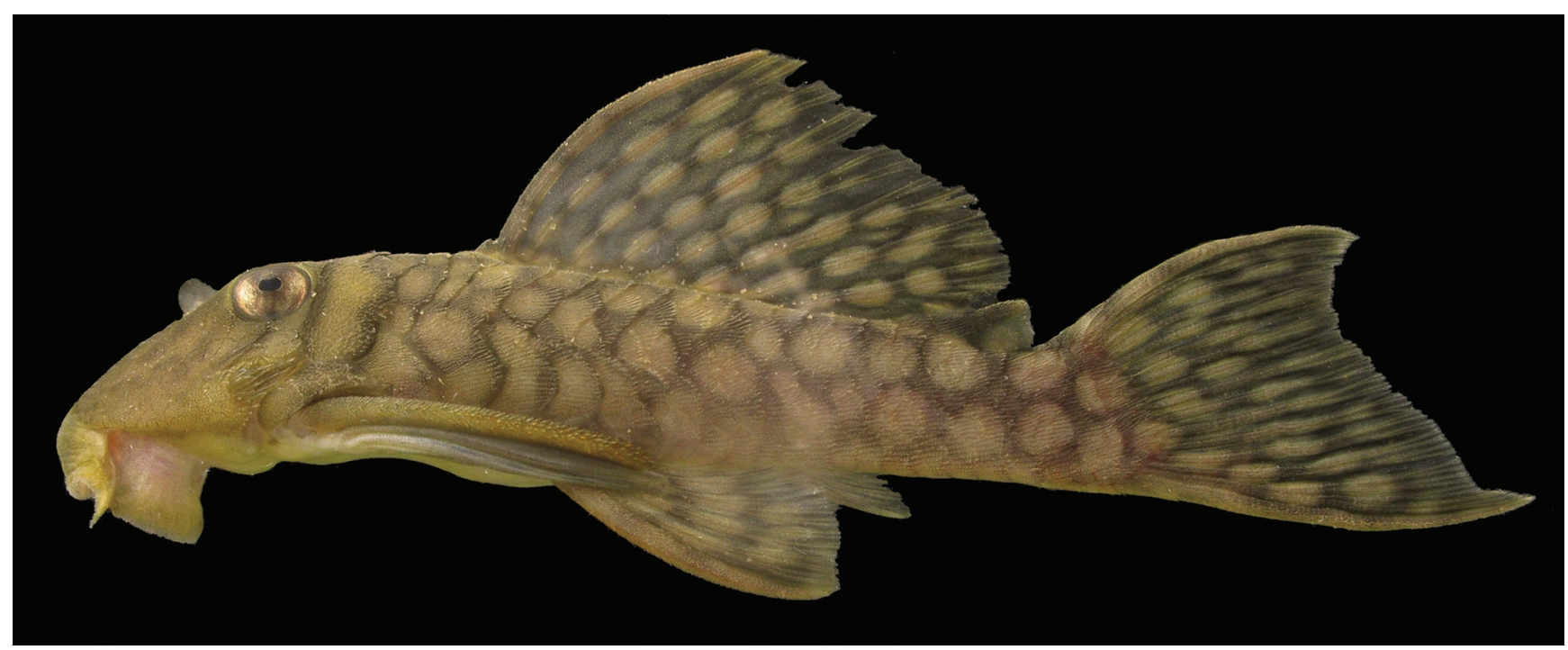

Fig. 15. Color in live of Spectracanthicus zuanoni. Image by J. Birindelli.

from that point to caudal-fin origin. Ventral profile straight from snout tip to origin of caudal fin. Ventral surface from tip of snout to urogenital papillae lacking plates, except for few small plates at pectoral and pelvic-fins origins. Body deep and robust even at caudal peduncle. Head and trunk lacking keels or ridges. Greatest body depth at dorsal-fin origin; lowest at caudal peduncle.

Head wide, convex dorsally; snout and cheeks completely covered by numerous small plates, except for small naked area on tip of snout. Snout slightly rounded in dorsal profile. Nasal elongated, L-shaped. Frontal short with a slight contact with nares anteriorly and orbit posteriorly. Anterior margin of frontal short, reaching posterior margin or half of length of nare. Parieto-supraoccipital short with posterior edge narrow, lacking crest. Sphenotic short, without contact with IO6, lacking conspicuous odontodes. Orbit enlarged (16.6-29.2\% HL), placed dorsolaterally in head. Iris with small dorsal flap over pupil. Pterotic-supracleithrum short with few fenestrae; anterior process forming most posterior margin of orbit. Posterior area of pterotic-supracleithrum with one plate.

Mouth moderate in size, nearly as long as wide. Lips large, covered with papillae; size of papillae decreasing towards posterior margin of lower lip; central buccal papilla absent. Upper lip folded over itself. Maxillary barbel short; base of barbel united to lips with free tip. Lower lip not reaching anterior margin of coracoid. Medial end of premaxillary teeth series almost straight. Premaxillae and dentaries narrow and elongate. Dentaries strongly curved inwards. Teeth medium size, well developed, slender, with long crown and large lateral cusp. Distal edge of teeth slightly curved inward. Eversible cheek plates with associated hypertrophied odontodes and disposed as unique block connected to opercle, that can be everted to approximately $90^{\circ}$ from head by opercle movements.

Body covered by five longitudinal series of plates supporting odontodes. Keels absent. Three to four predorsal plates; some small azygous predorsal plates sometimes present. Eight neural bifid spines supporting dorsal fin. Dorsalfin rays i,7, located posterior to neural spines of vertebral centra 6-17. Dorsal-fin base very long, its length equivalent to 12 dorsal plates, reaching pre-adipose plate and connected to adipose fin by thick membrane. Dorsal-fin spinelet V-shaped with lock mechanism. Pectoral and pelvic fins well developed, medial portion much expanded relative to base; distal margins rounded. Pectoral-fin rays i,6; unbranched ray covered with conspicuous odontodes. Tip of adpressed pectoral fin almost reaching vertical through medial, unbranched, pelvic-fin ray. Pelvic-fin rays i,5; pelvic-fin spine reaching vertical through anal-fin base when adpressed. Anal-fin rays i,4 located posterior to hemal spines of vertebral centra 15-17. Caudal-fin rays i,14,i, truncated; supracaudal plates. Five to six procurrent caudal-fin rays. Caudal peduncle strongly deep in lateral view. Total vertebrae 26, precaudal $8-12$. Sixth rib strongly thickened, remaining ribs slender. Infraorbital with 7-8 pores. Infraorbital 4 with little contact with orbit by posterior margin. Infraorbital 6 formed just postero-vental part of orbit. Lateral line pores restrict to hypural plate.

Color in alcohol. Dorsal surface of body and fins evenly brown covered by large white spots. Spots more frequent and conspicuous in dorsal and caudal fins than in pectoral, pelvic and anal fins. Some specimens, especially juveniles, can present overlapped spots forming smudges. Head poorly spotted, some individuals can present vermicular bands near snout region. Abdomen region ochre without spots. 
Table 5. Morphometric and meristic data of Spectracanthicus zuanoni. Values are given as percents of standard length or head length. $\mathrm{SD}=$ standard deviation.

\begin{tabular}{|c|c|c|c|c|c|c|}
\hline & $\begin{array}{c}\text { Holotype } \\
\text { INPA } 25874\end{array}$ & $\mathrm{n}$ & Min & $\operatorname{Max}$ & Mean & SD \\
\hline Standard length & 122.5 & 32 & 59.3 & 129.0 & 92.5 & - \\
\hline \multicolumn{7}{|c|}{ Percents of Standard Length } \\
\hline Head length & 44.4 & 32 & 32.7 & 42.1 & 36.0 & 1.9 \\
\hline Head depth & 26.2 & 32 & 18.1 & 29.1 & 21.7 & 2.6 \\
\hline Head width & 41.1 & 32 & 28.1 & 38.2 & 32.5 & 2.1 \\
\hline Body depth & 27.9 & 32 & 19.5 & 28.5 & 23.0 & 2.7 \\
\hline Body width at dorsal & 37.3 & 32 & 27.4 & 38.1 & 31.3 & 2.3 \\
\hline Body width at anal & 21.5 & 32 & 12.7 & 22.7 & 16.8 & 2.2 \\
\hline Predorsal length & 54.2 & 32 & 38.7 & 49.4 & 43.4 & 2.3 \\
\hline Postdorsal length & 26.4 & 32 & 19.2 & 27.7 & 22.7 & 2.0 \\
\hline Postanal length & 36.7 & 32 & 29.9 & 35.2 & 32.2 & 1.4 \\
\hline Dorsal-spine length & 39.3 & 32 & 28.0 & 36.7 & 32.5 & 3.0 \\
\hline Pectoral-spine length & 43.8 & 32 & 29.2 & 35.9 & 32.6 & 1.9 \\
\hline Pelvic-spine length & 36.4 & 32 & 23.6 & 33.6 & 29.1 & 2.5 \\
\hline Dorsal-base length & 44.4 & 32 & 20.5 & 41.7 & 34.2 & 4.4 \\
\hline $\begin{array}{l}\text { Caudal peduncle } \\
\text { depth }\end{array}$ & 19.7 & 32 & 14.5 & 20.8 & 16.8 & 1.7 \\
\hline \multicolumn{7}{|c|}{ Percents of Head Length } \\
\hline Snout length & 30.0 & 32 & 58.9 & 70.4 & 64.1 & 3.2 \\
\hline Interorbital width & 13.6 & 32 & 44.6 & 62.2 & 52.9 & 4.6 \\
\hline Orbital diameter & 7.7 & 32 & 16.6 & 29.2 & 23.5 & 3.5 \\
\hline \multirow[t]{2}{*}{ Dentary length } & 6.2 & 32 & 15.0 & 29.0 & 20.8 & 3.9 \\
\hline & Counts & & & & Mode & \\
\hline Premaxillary teeth & 14 & 32 & 6 & 25 & 14 & - \\
\hline Dentary teeth & 30 & 32 & 19 & 43 & 30 & - \\
\hline Dorsal-fin rays & $\mathrm{i}+7$ & 32 & $i+7$ & $i+7$ & $\mathrm{i}+7$ & - \\
\hline Pectoral-fin rays & $i+6$ & 32 & $i+6$ & $i+6$ & $\mathrm{i}+6$ & - \\
\hline Pelvic-fin rays & $\mathrm{i}+5$ & 32 & $i+5$ & $i+5$ & $\mathrm{i}+5$ & - \\
\hline Anal-fin rays & $i+4$ & 32 & $i+4$ & $i+4$ & $\mathrm{i}+4$ & - \\
\hline Caudal-fin rays & $\mathrm{ii}+14$ & 32 & $\mathrm{ii}+14$ & $\mathrm{ii}+14$ & $\mathrm{ii}+14$ & - \\
\hline Lateral line plates & 23 & 32 & 21 & 25 & 22 & - \\
\hline $\begin{array}{l}\text { Caudal peduncle } \\
\text { plates }\end{array}$ & 8 & 32 & 7 & 8 & 7 & - \\
\hline
\end{tabular}

Geographic distribution. Spectracanthicus zuanoni is known from the rio Xingu basin, near Altamira and Belo Monte, Pará State, Brazil (Fig. 5).

Etymology. The specific epithet is in honor to Jansen Zuanon (INPA) due to his contribution to the knowledge of Neotropical Ichthyology. Jansen Zuanon was also the first ichthyologist who collected and identified this species as a new one.

Fishery and economical importance. Spectracanthicus zuanoni is also recognized as "acari bola branca", L020 and
L354 (L-number; Schraml \& Schafer, 2004) by aquarists and local fishermen. As in Itaituba and Santarém, at rio Tapajós, Altamira is also known for its ornamental fishery activities.

Ecological notes. Spectracanthicus zuanoni is a nocturnal species that feeds on algae and other food items off periphyton by grazing over rock bottom. According to Zuanon (1999) and Rapp Py-Daniel \& Zuanon (2005), Spectracanthicus zuanoni is a moderate reophilic species that is found in rock-bottom areas subjected to backwater and strong currents. Specimens were found individually or in groups of three, under shelter boulders (adults) and spaces beneath rocks (juveniles), up to $2 \mathrm{~m}$ deep. The juveniles share the shelters with other loricariids such as Ancistrus sp., A. ranunculus, Baryancistrus xanthellus, Spectracanthicus punctatissimus, Hopliancistrus tricornis, Parancistrus nudiventris, Peckoltia vittata, and Pseudancistrus aff. barbatus.

\section{Discussion}

Isbrücker (1980) and Schaefer $(1986,1987)$ diagnosed the Ancistrini (sensu Armbruster, 2004) according to the presence of evertible cheek plate, usually bearing hypertrophied odontodes, a feature also present in Pterygoplichthyini. However, according to Armbruster (2004), the Pterygoplichthyini are distinguished from Ancistrini the by the presence of a connective tissue covering the stomach. Characters like the eversible cheek plates and presence of four umbranched anal-fin rays, present in most of Ancistrini taxa, are both absent in Spectracanthicus murinus, due to reversion.

The most evident character that distinguishes Spectracanthicus from other loricariids is the membranous connection between dorsal and adipose fins. Although such feature is present in other loricariid genera (i.e., Baryancistrus and Parancistrus), other characters readily distinguish these from Spectracanthicus: the mesial wall of the metapterygoid being much taller than the lateral; the spoon-shaped anterior process of the metapterygoid; and the presence of a deep pouch on the lateral ethmoid (Armbruster, 2004). Chamon (2012) proposed four additional synapomorphies supporting the monophyly of the genus: the presence of a cartilaginous second basibranchial; the pointed distal margin of the Weberian apparatus transverse process; the short hypurapophysis; and a great hiatus between the inferior hypural lobe and last hemal spine. All synapomorphies proposed in the aforementioned studies were observed in all species of Spectracanthicus recognized herein. In addition to these features, all species of Spectracanthicus (except S. immaculatus) share the contact between sphenotic and IO6; the elongate anterior metapterygoid process; and the enlogate lateropterygium, not surpassing the vertical through the anterolateral process of the basipterygia. 
Although species of Spectracanthicus can be distinguished from each other based on morphological features, they can be promptly diagnosed from each other by their color pattern. In fact, the color pattern is a very useful source of characters allowing the identification of loricariid fishes, but some intraspecific variation is often common, (as with other characters sources) and must be considered. Such plasticity has rendered fishermen and aquarists to recognize specimens, falling into that variation, as different species. Specimens of Spectracanthicus puntatissimus, for instance, are recognized under different L numbers (Schraml \& Schaefer, 2004) according to the amount and size of the spots, and its occurrence along the rio Xingu: L016 (specimens from Altamira); L030 (specimens from Belo Monte); and L353 (specimens from the rio Iriri). Some other characters referring to the shape of the snout and teeth number are also employed to justify the recognition of these specimens as different species, but these differences are not constant in each subpopulation. A similar scenario can be observed for S. zuanoni, with different subpopulations along the rio Iriri (L354). It is not uncommon, thought, to find further variations on the color pattern of all aforementioned subpopulations, which hinders the recognition of populations as independent species within the genus.

All species studied in the present contribution have commercial interest as ornamental fish. The ornamental fish exploration has been a common practice in the rio Xingu and rio Tapajós regions for the last 30 years. These activities have become economically profitable within some communities of these regions and, in many cases, constitute the entire source of income for several families. According to Rapp Py-Daniel \& Zuanon (2005) and Camargo et al. (2011) this practice has become most frequent in Altamira since end of the1980's, when gold prospectors that lost their jobs began to collect loricariids fish. The capture of attractive species for the ornamental fish trade was possible with the adaptation of old techniques employed in gold prospect at great depths (up to 15 meters), such as the use of air compressors, diving masks and lanterns. From this period several loricariid species have become known worldwide. Presently, the Xingu and Tapajós drainages together constitute one of the largest sources of ornamental fish of the family Loricariidae. In the rio Xingu the ornamental fishery activities is very intense, especially at Altamira, Senador José Porfírio, Belo Monte, Vitória do Xingu, and Porto de Moz (Camargo et al., 2011; L. M. Sousa, pers. comm.). On the other hand, at rio Tapajós the ornamental fish activities are concentrated at Santarém and Itaituba (Sousa \& Birindelli, 2009). In the rio Tocantins, the ornamental fishery is also a common practice concentrated at Marabá region.

According to Andrews (1990) two of the major ways in which the market for ornamental fish can affect natural populations are the introduction of exotic species and the direct decrease of stocks by fishing. Among fish species that are endangered, only a small number of these have commercial interest as ornamental. In relation to rio Xingu ichthyofauna, it is forbidden to capture some species for ornamental purpose when the decline of these populations is remarkable, for instance Hypancistrus zebra that was considered endangered according to Normative Instruction MMA 05/2004 of the Brazilian Goverment.

For the majority of the ornamental loricariid fish species from Amazon basin, the most imminent danger is the construction of dams. In the case of rio Xingu, the project of Belo Monte Dam includes a major barrage located $40 \mathrm{~km}$ downstream from the city of Altamira (Volta Grande region), forming the reservoir Xingu. As a consequence, areas of the River with current water will give rise to a large lake of standing water. Fish that live in this type of environment are not adapted to slow flowing waters or lenthic environments which are low in oxygen. Furthermore, dozens fish species that exist only at the Volta Grande may disappear, because while the region is a lotic environment, it will not keep sufficient flow to maintain such species (L. M. Sousa, pers. comm.). The Xingu Spectracanthicus species are widely distributed along the rio Xingu and have several subpopulations. In this case, some of these subpopulations may be greatly reduced or even become locally extinct, but the species as a whole will probably not be extinguished, since it will remain in little or non-impacted areas where the water reaming is current. The same scenario may be expected to occur with $S$. zuanoni, even though its subpopulations are smaller than S. puctatissimus.

The construction of a complex of five dams at rio Tapajós and rio Jamaxim is already scheduled: São Luiz do Tapajós and Jatobá, on rio Tapajós; and Cachoeira dos Patos, Jamanxim and Cachoeira do Caí on the rio Jamanxim (Fernandes et al., 2010). Regarding S. murinus, which has relatively high abundance in the region of Itaituba, such impacts can directly affect the population due to habitat loss. However, as the species has a wide distribution along the rio Tapajós, some subpopulations will probably not be impacted by habitat loss, being restricted to regions where the environment remains lotic. Concerning $S$. immaculatus, although it has little representation in scientific collections, it is abundant at the region and this fact can be explaned by the lack of specific capture effort.

In rio Tocantins, the Tucuruí Dam construction was completed in 1981 and, as in others dams, the change from a lotic to a lenthic habitat was considered a major environmental interference, because of the effects to the aquatic ecosystem in general. The formation of the lake resulted on major changes in the fish fauna of the rio Tocantins, promoted by disruption of migratory routes and the disappearance of some species (Mérona et al., 2010). Although Spectracanthicus tocantinensis is mentioned in several web sites of ornamental fish as Spectracanthicus sp. 
L086, LDA014, their representation in scientific collections is relatively low and the last samples were collected in 1984. This decrease of sampling at Tucuruí and Cametá regions may be related to deficient collection effort for ornamental fisheries. Furthermore, the species seems to occur in abundance at Marabá region, where it is commercialized for several regions in the country (H. Anatole, pers. comm.)

Given the current scenario of investment in hydropower energy in the Brazilian Amazon, it can be stated that fish species that are directly dependent on rapid waters with high oxygen content are in threat. Obviously, species with a wide distribution along certains Amazonian rivers or in several drainages will be safe. On the other hand, species that are naturally rare, usually restricted to specific habitats and localities, may suffer a drastic population decline and even become extinct.

\section{Key to the species of Spectracanthicus}

1a. Triangle-shaped opercle lacking large eversible odontodes; three anal-fin branched rays. S. murinus

1b. Bar-shaped opercle with large eversible odontodes; four anal-fin branched rays 2

2a. Ground color of body dark gray without dots or spots ......... S. immaculatus

2b. Body dark brown to black with small yellowish dots or spots, or body dark gray without dots or spots

3a. Body with large (similar to slightly larger eye diameter) white spots S. zuanoni

3b. Body with pale/yellowish, small- to medium-sized (clearly smaller than eye diameter) dots .. 4

4a. Dorsal profile of snout slightly pointed, few premaxillary and dentary teeth (5-8 and 8-16 respectively)

S. tocantinensis

4b. Dorsal profile of snout rounded, numerous premaxillary and dentary teeth (12-17 and 21-30 respectively)

S. punctatissimus

\section{Acknowledgments}

Authors wish to thank Jonathan Armbruster (AUM), Jansen Zuanon (INPA), Sonia Fisch-Müller (MHNG), Marcelo Britto and Paulo Buckup (MNRJ), Helmut Wellendorf (NMW), Michel Gianetti and Osvaldo Oyakawa (MZUSP) and Hielke Praagman (ZMA) for the hospitality during visits to the fish collections under their care, for loan of specimens provide collection data information. Thanks are also due to José Birindelli (UEL) and Leandro Sousa (UFPA) for permission to use their images of live specimens, and Eduardo Baena for the osteological structures images. The manuscript was also improved by the valuable suggestions and comments of André Netto-Ferreira, Fabio Gaiger, José Birindelli and two anonymous reviewers. CCC was funded by FAPESP (proc. 2007/07770-5).

\section{Literature Cited}

Armbruster, J. W. 2004. Phylogenetic relationships of the suckmouth armoured catfishes (Loricariidae) with emphasis on the Hypostominae and the Ancistrinae. Zoological Journal of Linnean Society, 141: 1-80.

Arratia, G. \& L. Huaquin. 1995. Morphology of the lateral line system and the skin of diplomystid and certain primitive loricarioid catfishes and systematic and ecological considerations. Bonner Zoologische Monographien, 36: 5-109.

Andrews, C. 1990. The ornamental fish trade and fish conservation. Journal of Fish Biology, 37: 53-59.

Burgess, W. E. \& L. Finley. 1996. An atlas of freshwater and marine catfishes: Update. Tropical Fish Hobbyist, 1996: 163-174.

Camargo, M., J. Carvalho Júnior \& R. A. Estupiñan. 2001. Peixes Comerciais da Ecorregião Aquática Xingu-Tapajós. Pp. 175-192. In: Castilhos, Z. C. \& P. A. Buckup (Eds.). Ecorregião Aquática Xingu-Tapajós. Rio de Janeiro, CETEM.

Camargo, M., H. Gimênes Junior \& L. H. Rapp Py-Daniel. 2012. Acaris ornamentais do Médio Rio Xingu. Belém, FAPESPA/ FUNCEFET.

Chamon, C. C. 2012. Revisão taxonômica e relações filogenéticas do grupo Acanthicus (Siluriformes, Loricariidae). Unpublished Ph.D. Dissertation, Universidade de São Paulo, São Paulo, 270p.

Eigenmann, C. H. \& R. S. Eigenmann. 1889. Preliminary notes on South American Nematognathi. II. Proceedings of the California Academy of Sciences, 2: 28-56.

Eschmeyer, W. N. (Ed.). 1998. Catalog of fishes. Special publication, California Academy of Sciences, San Francisco.

Fernandes, F. R. C., G. R. Silva, M. H. M. R. Lima, N. S. Teixeira \& R. B. R. Villa Verde. 2001. A Ecorregião Aquática Xingu-Tapajós na Amazônia: Abordagem Demográfica, Econômica e Social. Pp. 59-102. In: Castilhos, Z. C. \& P. A. Buckup (Eds.). Ecorregião Aquática Xingu-Tapajós. Rio de Janeiro, CETEM.

Ferraris, C. J. Jr. 2007. Checklist of catfishes, recent and fossil (Osteichthyes: Siluriformes), and catalogue of siluriform primary types. Zootaxa, 1418: 1-628.

Fisch-Müller, S. 2003. Subfamily Ancistrinae (Armored catfishes). Pp. 373-400. In: Reis, R.E., S.O. Kullander \& C. J. Ferraris Jr. (Eds.). Check list of the Freshwater Fishes of South and Central America. Porto Alegre, Edipucrs, 729p.

Higuchi, H. 1996. An updated list of ichthyological collecting stations of the Thayer Expedition to Brazil (1865-1866). Available from: http:/www.mcz.harvard.edu/Departments/Fish/thayer. htm. (May 2013).

Fowler, H. W. 1914. Fishes from the Rupununi River, British Guiana. Proceedings of The Academy of Natural Science of Philadelphia, 66: 229-284.

Isbrücker, I. J. H. 1980. Classification and catalog of the mailed Loricariidae (Pisces, Siluriformes). Verslagen en Techniche Gegevens, Instituut voor Taxonomische Zoölogie, Universiteit van Amsterdam, 22: 1-181.

Isbrücker, I. J. H. \& H. Nijssen. 1991. Hypancistrus zebra, a new genus and species of uniquely pigmented ancistrine loricariid fish from the rio Xingu, Brazil (Pisces: Siluriformes: Loricariidae). Ichthyological Exploration of Freshwaters, 1: 345-350. 
Kner, R. 1853. Die Hypostomiden. Zweite Hauptgruppe der familie der Panzerfische. (Loricata vel Goniodontes). Denkschriften der Kaiserlichen Akademie der Wissenschaften, 7: 251-286.

Lujan, N. K., M. Arce \& J. W. Armbruster. 2009. A new black Baryancistrus with blue sheen from the upper Orinoco (Siluriformes: Loricariidae). Copeia, 2009: 50-56.

Lundberg, J. G. \& J. N. Baskin. 1969. The caudal skeleton of the catfishes, order Siluriformes. American Museum Novitates, 2398: 1-49.

Mérona, B. Juras, A. A., Santos, G. M. \& I. H. A. Cintra. 2010. Os peixes e a pesca no rio Tocantins: vinte anos depois da UHE Tucuruí. Brasília, Centrais Elétricas do Norte do Brasil, Eletronorte.

Rapp Py-Daniel, L. H. 1989. Redescription of Parancistrus aurantiacus (Castelnau, 1855) and preliminary establishment of two new genera: Baryancistrus and Oligancistrus (Siluriformes, Loricariidae). Cybium, 13: 235-246.

Rapp Py-Daniel, L. H. \& J. A. Zuanon. 2005. Description of a new species of Parancistrus (Siluriformes: Loricariidae) from the rio Xingu, Brazil. Neotropical Ichthyology, 3: 571-577.

Reis, R. E., E. H. L. Pereira \& J. Armbruster. 2006. Delturinae, a new loricariid catfish subfamily (Teleostei: Siluriformes), with revisions of Delturus and Hemipsilichthys. Zoological Journal of Linnean Society 147: 277-299.

Reis, R. E., S. O. Kullander \& C. J. Ferraris. 2003. Family Loricariidae. Pp. 318. In: Reis, R. E., S. O. Kullander \& C. J. Ferraris. (Eds.). Checklist of the freshwater fishes of South and Central America. Porto Alegre, Edipucrs.
Schaefer, S. A. 1987. Osteology of Hypostomus plecostomus (Linnaeus), with a phylogenetic analysis of the loricariid subfamilies (Pisces, Siluroidei). Contributions in Sciences, Natural History Museum of Los Angeles County, 394: 1-31.

Schaefer, S. A. 1986. Historical Biology of the loricariid catfishes: phylogenetics and functional morphology. Unpublished Ph.D. Dissertation, The University of Chicago, Chicago, 290p.

Schraml, E. \& F. Schafer. 2004. Aqualog: Loricariidae All L-Numbers. Rodgau, Hollywood Import \& Export, Inc., $2^{\text {nd }}$ Edition.

Sousa, L. M. \& J. L. O. Birindelli. 2009. Acaris do Tapajós. Habitat, 84: 8-19.

Steindachner, F. 1881. Beitrage zur Kenntniss der Flussfische $\mathrm{Su}$ damerika's. II. Denkschriften der MathematischNaturwissenschaftlichen Classe der Kaiserlichen Akademie der Wissenschaften in Wien, 43: 103-146

Taylor, W. R. \& G. C. Van Dyke. 1985. Revised procedures for staining and clearing small fishes and other vertebrates for bone cartilage. Cybium, 9: 107-119.

Werner, A., W. Lechner \& J. Schmidt. 2005. Miniatlas - L-Welse - L1 bis L400. Ruhmannsfelden, Bede-Verlag.

Zuanon, J. A. 1999. História natural da ictiofauna de corredeiras do rio Xingu, na região de Altamira, Pará. Unpublished Ph.D. Dissertation, Universidade Estadual de Campinas, Campinas, 199p.

Submitted August 4, 2012

Accepted November 19, 2013 by Francisco Langeani

Published March 31, 2014 